\title{
Stretch-mediated Release of Angiotensin II Induces Myocyte Apoptosis by Activating p53 That Enhances the Local Renin-Angiotensin System and Decreases the Bcl-2-to-Bax Protein Ratio in the Cell
}

\author{
Annarosa Leri,, \\ Jan Kajstura, ${ }^{*}$ and Piero Anversa* \\ *Department of Medicine, New York Medical College, Valhalla, New York 10595; and ${ }^{\star D e p a r t m e n t s ~ o f ~ P a t h o l o g y, ~ A n a t o m y, ~ a n d ~ C e l l ~}$ \\ Biology and Institute for Cancer Research and Molecular Medicine, Jefferson Medical College, Philadelphia, Pennsylvania 19107
}

\begin{abstract}
Physical forces activate apoptosis and gene expression, but the mechanism is unknown. For this purpose, adult myocytes were stretched in an equibiaxial stretch apparatus and the magnitude of cell death was examined 4 and $24 \mathrm{~h}$ later. The possibility of stretch-mediated activation of p53 and p53-dependent genes was evaluated at $30 \mathrm{~min}, 2,4,8$, and $24 \mathrm{~h}$. Myocyte apoptosis increased by 4.4 - and 7.6-fold at 4 and $24 \mathrm{~h}$ after stretch. p53 binding to the promoter of angiotensinogen, $\mathrm{AT}_{1}$ receptor, and Bax also increased. Expression of angiotensinogen, $\mathrm{AT}_{1}$ receptor, p53, and $\mathrm{Bax}$ increased and Bcl-2 decreased in stretched myocytes. The changes in $\mathrm{AT}_{1}$ receptor, p53, Bax, and Bcl-2 became more apparent with the duration of stretch. Angiotensin II concentration in the medium increased at $10 \mathrm{~min}$, reaching maximal levels at 1 and $20 \mathrm{~h}$. The $\mathrm{AT}_{1}$ blocker, losartan, abolished apoptosis in stretched myocytes. Myocyte volume was not influenced by stretch. In conclusion, stretch-mediated release of angiotensin II is coupled with apoptosis and the activation of p53 which may be responsible for the prolonged upregulation of the local renin-angiotensin system and the increased susceptibility of myocytes to undergo apoptosis. (J. Clin. Invest. 1998. 101:1326-1342.) Key words: mechanical stress - cell death $•$ renin-angiotensin system $\bullet$ protein $\mathrm{p} 53 \cdot$ gene expression regulation
\end{abstract}

\section{Introduction}

Heart disease of ischemic and nonischemic origin is characterized by abnormal changes in myocardial loading that activate a variety of cellular responses $(1,2)$, including apoptotic myocyte cell death (3-5). Ventricular decompensation and failure impose an elevated diastolic load on myocytes, resulting in stretching of sarcomeres $(6,7)$ and the stimulation of multiple second messenger systems which have been linked to the initiation of myocyte reactive hypertrophy in the pathologic heart $(8-12)$. Although not all studies are in agreement $(13,14)$, the

Address correspondence to Piero Anversa, M.D., Department of Medicine, Vosburgh Pavilion, Room 302, New York Medical College, Valhalla, NY 10595. Phone: 914-594-4168; FAX: 914-594-4406.

Received for publication 3 April 1997 and accepted in revised form 24 January 1998.

J. Clin. Invest.

(c) The American Society for Clinical Investigation, Inc. 0021-9738/98/04/1326/17 \$2.00

Volume 101, Number 7, April 1998, 1326-1342

http://www.jci.org autocrine release of angiotensin II (Ang II) ${ }^{1}$ has been proposed as the biochemical signal responsible for the translation of physical forces into molecular events and the modulation of myocyte growth (15-18). Ang II triggers apoptosis of neonatal (19) and adult (20) ventricular myocytes in vitro, suggesting that abnormal levels of resting tension may lead to the local release of Ang II and the induction of programmed cell death in the myocardium (21). This hormone may affect cell size and number, the principal determinants of wall and chamber remodeling in the overloaded ventricle (22). Since myocyte apoptosis occurs in the severely impaired heart acutely and chronically (3-5, 23-26), the question concerns the identification of the mechanism of prolonged stimulation of the cellular reninangiotensin system (RAS). Recent observations indicate that overexpression of p53 in myocytes, induced by a replicationdeficient adenoviral vector, upregulates transcription of angiotensinogen (Aogen) and $\mathrm{AT}_{1}$ receptors, leading to the formation of Ang II and apoptotic cell death (27). Importantly, the quantity of p53 in infected myocytes increased with time in the absence of the adenovirus but in the presence of Ang II, raising the possibility that this peptide may positively regulate p53 (27). On this basis, the hypothesis was advanced that sarcomere elongation in vitro results in Ang II release and activation of p53 and p53-dependent genes. Since imperfect p53 binding sites are present in the promoter of Aogen and $\mathrm{AT}_{1}$ receptor genes (27), p53 may enhance the myocyte RAS and the generation of Ang II. The newly formed Ang II may reactivate the system, sustaining Ang II synthesis and programmed cell death. Additionally, p53 is a transcriptional modulator of the Bax gene which promotes apoptosis (28), and a p53 negative response element has been identified in the Bcl-2 gene which protects from apoptosis (29). Therefore, adult ventricular myocytes were stretched in an equibiaxial stretch apparatus for periods varying from $10 \mathrm{~min}$ to $24 \mathrm{~h}$ and the concentration of Ang II in the medium, magnitude of apoptosis, p53 binding to the promoter of Aogen, $\mathrm{AT}_{1}$ receptor, and Bax genes, as well as the expression of Aogen, $\mathrm{AT}_{1}$ receptor, p53, Bcl-2, and Bax in the cells were determined. Finally, the occurrence of myocyte hypertrophy was evaluated by measuring protein content per cell by confocal microscopy.

\section{Methods}

Myocyte isolation. Hearts from 3-mo-old Sprague-Dawley rats (Charles River Breeding Laboratories, North Wilmington, MA) were

1. Abbreviations used in this paper: ANF, atrial natriuretic factor; Ang II, angiotensin II; Aogen, angiotensinogen; CM, conditioned medium; HEDAF, 5-hexadecanoylaminofluorescein; RAS, reninangiotensin system; SFM, serum-free medium; TdT, terminal deoxynucleotidyl transferase. 
excised and myocytes were enzymatically dissociated $(20,23,25,30)$. Rectangular, Trypan blue-excluding cells constituted nearly $80 \%$ of all myocytes. The number of viable myocytes obtained from the left ventricle was $6 \times 10^{6}$.

Cell culture and equibiaxial stretch apparatus. Myocytes were plated at a density of $2 \times 10^{4}$ cells $/ \mathrm{cm}^{2}$ in a device that results in homogenous equibiaxial strains of $0-20 \%$ to a culture rubber substrate (31) coated with $0.5 \mu \mathrm{g} / \mathrm{cm}^{2}$ laminin (Sigma Chemical Co., St. Louis, MO). Cells were incubated in serum-free medium (SFM) (20) for $24 \mathrm{~h}$ to adhere to the substrate before stretching. Stretching corresponded to a $9 \%$ increase in sarcomere length, measured at a magnification of 1,000 by averaging groups of 10 sarcomeres each in 300 cells in each preparation. To evaluate whether stretching per se was associated with cell injury, cultures were exposed to 5-hexadecanoylaminofluorescein (HEDAF) (Molecular Probes, Inc., Eugene, OR). HEDAF is integrated exclusively in the plasma membrane of intact cells, diffusing to the cytoplasm in the presence of membrane breakage (32). The percentage of damaged myocytes was measured by confocal microscopy after incubation with $5 \mu \mathrm{M}$ HEDAF in PBS for $1 \mathrm{~min}$ at room temperature. This parameter was evaluated in nonstretched and stretched myocytes at $30 \mathrm{~min}, 4,12$, and $24 \mathrm{~h}$. For the actual study, nonstretched and stretched myocytes were examined at 10 and $30 \mathrm{~min}, 1,2,4,8,12,16$, 20 , and $24 \mathrm{~h}$. In some cultures, the $\mathrm{AT}_{1}$ receptor antagonist, losartan (Merck, Rahway, NJ), was added to myocytes at $10^{-7} \mathrm{M}(20), 30 \mathrm{~min}$ before stretch, and kept for the period of observation. In other experiments, cultures of nonstretched myocytes were exposed to $10^{-9} \mathrm{M}$ Ang II. The peptide was added twice over a period of $3.5 \mathrm{~h}$ and cells were harvested at 4 and $24 \mathrm{~h}$ after the first administration of Ang II. For histochemistry, cells were washed with cold HBSS, fixed on ice in $1 \%$ formaldehyde for $20 \mathrm{~min}$, and stored in $70 \%$ ethanol at $-20^{\circ} \mathrm{C}$ for 1-3 d. For molecular determinations, cells were collected in cold PBS, centrifuged at $12,000 \mathrm{~g}$, and stored at $-75^{\circ} \mathrm{C}$.

In situ terminal deoxynucleotidyl transferase (TdT) assay. Cultures were covered with $50 \mu \mathrm{l}$ of solution containing $5 \mathrm{U}$ of TdT, $1.5 \mathrm{mM}$ $\mathrm{CoCl}_{2}, 0.2 \mathrm{M}$ potassium cacodylate, $25 \mathrm{mM}$ Tris- $\mathrm{HCl}, 0.25 \% \mathrm{BSA}$, and $0.5 \mathrm{mM}$ biotin-16-dUTP. After exposure to a solution containing $5 \mu \mathrm{g} / \mathrm{ml}$ FITC labeled Extravidin (Sigma Chemical Co.), nuclei were visualized with bisbenzimide (25). The fraction of myocytes with DNA cleavage was determined by examining by light microscopy 2,000 myocytes in each culture and counting nuclei with green fluorescence $(19-21,25)$. This analysis was confirmed in 300 cells per preparation by confocal microscopy.
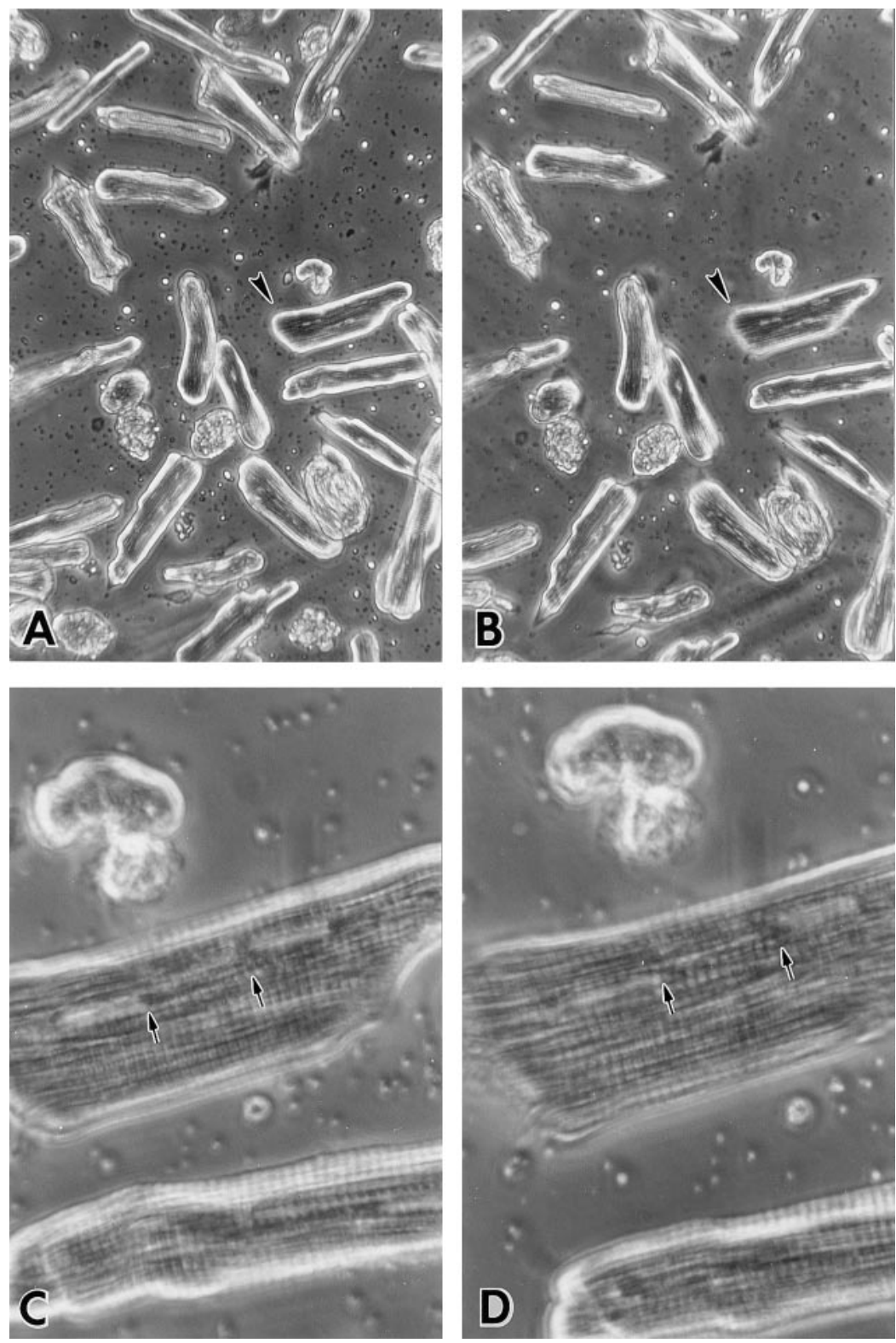

Figure 1. Effects of stretch on myocytes cultured in SFM for $24 \mathrm{~h}$. Arrowheads in $A$ and $B$ illustrate the same myocyte before $(A)$ and after $(B)$ stretching. The changes in sarcomere length in the same cell before $(C)$ and after $(D)$ stretching are shown by arrows. The average increase in sarcomere length in this preparation was nearly $10 \%$. Phase-contrast microscopy: $A$ and $B, \times 180 ; C$ and $D, \times 750$. 
In situ ligation. Double strand DNA fragments for in situ ligation to $3^{\prime}$ overhangs were prepared using primers $5^{\prime}$-ATGCTCTTCAGTTCGTGTGT-3' and 5'-CTGACTTGGCAGGCTTGAGG-3' complementary to pOCME1B plasmid $(33,34)$. The reaction included $50 \mathrm{mM}$ Tris- $\mathrm{HCl}, \mathrm{pH} 8.3,10 \mathrm{mM} \mathrm{KCl}, 1.5 \mathrm{mM} \mathrm{MgCl}, 16.6 \mu \mathrm{M}$ tetramethylrhodamine-6-dUTP (Boehringer Mannheim, Indianapolis, IN), $16.6 \mu \mathrm{M}$ TTP, $50 \mu \mathrm{M}$ of dATP, dCTP, and dGTP, $100 \mathrm{pmol}$ of each primer, and $10 \mathrm{pg}$ of plasmid. Taq polymerase $(2.5 \mathrm{U})$ was added to the reaction after heating to $80^{\circ} \mathrm{C}$. PCR was performed with 35 cycles of $20 \mathrm{~s}$ at $95^{\circ} \mathrm{C}, 20 \mathrm{~s}$ at $61^{\circ} \mathrm{C}$, and $120 \mathrm{~s}$ at $74^{\circ} \mathrm{C}$, the final cycle having an extension time of $4 \mathrm{~min}$. The product was precipitated with $2.5 \mathrm{M}$ ammonium acetate and $70 \%$ ethanol. Tetramethylrhodamine-6dUTP-labeled fragments were ligated to DNA using T4 DNA ligase $(33,35)$. A mixture of $50 \mathrm{mM}$ Tris- $\mathrm{HCl}, \mathrm{pH} 7.8,10 \mathrm{mM} \mathrm{MgCl}, 10 \mathrm{mM}$ DTT, $1 \mathrm{mM}$ ATP, $25 \mu \mathrm{g} / \mathrm{ml}$ BSA, 15\% polyethylene glycol 8,000, $1 \mu \mathrm{g} /$ $\mathrm{ml}$ probe, and $25 \mathrm{U} / \mathrm{ml}$ DNA T4 ligase was applied for $1 \mathrm{~h}$ and washed with water at $70^{\circ} \mathrm{C}$. An analysis identical to the TdT assay was used.

DNA gel electrophoresis. Myocytes, $1.5 \times 10^{6}$, were fixed in $70 \%$ ethanol and incubated in $40 \mu \mathrm{l}$ of phosphate-citrate buffer ( $\mathrm{pH} 7.8$ )

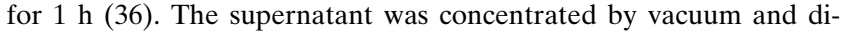
gested with RNase $(1 \mathrm{mg} / \mathrm{ml})$ and proteinase $\mathrm{K}(1 \mathrm{mg} / \mathrm{ml})(19-21,25)$.

RIA. Ang II was measured in conditioned medium (CM) at 10 min, $1,4,8,12,16$, and $20 \mathrm{~h}$. Losartan, $10^{-7} \mathrm{M}$, was added $1 \mathrm{~h}$ before $\mathrm{CM}$ collection. At $10 \mathrm{~min}$ and $1 \mathrm{~h}$, losartan was added before stretching. RIA was done with a Peninsula kit (Belmont, CA).

Ang II antibody labeling. Cultures, fixed in $3.7 \%$ formaldehyde, were incubated with rabbit antiserum to Ang II (Peninsula) diluted 1:20 in PBS and with rhodamine-labeled goat anti-rabbit IgG. Specificity was determined by preabsorption of $10 \mu \mathrm{l}$ of antibody with 0.05 $\mathrm{mg}$ of antigen for $2 \mathrm{~h}$ at $37^{\circ} \mathrm{C}$. Nonimmune rabbit serum was also used as a control (37).

Mobility shift assay of p53 binding activity. To prepare a doublestranded probe for bax, oligonucleotides 5'-AGCTTGCTCACAAGTTAGAGACAAGCCTGGGCGTGGCTATATTGA-3' and 5' - AGCTTCAATATAGCCCACGCCCAGGCTTGTCTCTAACTTGTGAGCA-3' (38), which contain a perfect and three imperfect consensus motifs of p53 from the human bax gene promoter (28), were annealed and labeled with $\left[\gamma_{-}{ }^{32} \mathrm{P}\right] \mathrm{ATP}$ and T4 polynucleotide kinase (Boehringer Mannheim). The sequence corresponds to -492 to -447 bp located $70 \mathrm{bp} \mathrm{5'}$ of the TATAA bax (GenBank U17193). To prepare probe for $\mathrm{AT}_{1}$, oligonucleotides $5^{\prime}$-ATTTAATTAACATGCCTGTGACTTT-3' and 5'-AAAGTCACAGGCATGT-
TAATTAAAT- $3^{\prime}$ which correspond to rat $\mathrm{AT}_{1}$ sequence from -1862 to -1838 bp located 1813 bp $5^{\prime}$ of the TATAA box (GenBank S66402) were used. To prepare probe for Aogen, oligonucleotides 5'-CTTCCATCCACAAGCCCAGAACATT-3' and 5'-AATGTTCTGGGCTTGTGGATGGAAG-3' which correspond to rat Aogen sequence from -599 to -575 bp located 568 bp $5^{\prime}$ of the TATAA box (GenBank M31673) were used (27). Nuclear extracts were obtained by incubation of myocytes and SV-T2 cells overexpressing p53 (American Type Culture Collection, Rockville, MD) with hypotonic buffer (27). Cells were mixed with 10\% NP-40 and centrifuged, nuclear pellets were incubated in high-salt buffer and centrifuged, and the supernatant was collected (27). Nuclear extracts (20-40 $\mu \mathrm{g}$ of protein) were incubated in $10 \%$ glycerol, $20 \mathrm{mM} \mathrm{MgCl}_{2}, 10 \mathrm{mM}$ DTT, $200 \mathrm{mM} \mathrm{NaCl}, 200 \mathrm{mM}$ Hepes, $\mathrm{pH}$ 7.9, $1.0 \mathrm{mM}$ PMSF, for $10 \mathrm{~min}$ on ice. $2 \mu \mathrm{l}$ of $\left[{ }^{32} \mathrm{P}\right]$-labeled probe was added and the reaction mixture was incubated at room temperature. In some experiments, nuclear extracts were incubated with anti-p53 antibodies ( $0.5 \mu \mathrm{g}$ of PAb240; Santa Cruz Biotechnology, Santa Cruz, CA; or PAb122; Boehringer Mannheim). Samples were subjected to electrophoresis in $4 \%$ polyacrylamide gel. Controls for specificity included unlabeled bax, $\mathrm{AT}_{1}$, and Aogen probes as competitors and unlabeled mutated bax probe (5'-AAGTTAGAGATAATGCTGGGCGAG-3' and 5'-CTCGCCCAGCATTATCTCTAACTT-3') as noncompetitor.

Northern blot analysis. Total RNA $(20 \mu \mathrm{g})$ was size-separated by electrophoresis in $1.0 \%$ agarose-formaldehyde gel, transferred to nitrocellulose membrane, and cross-linked (27, 30). Atrial natriuretic factor (ANF) cDNA (600 bp) was released from $\mathrm{pBF} / \mathrm{ANF}$ plasmid (obtained from Dr. Cricket Seidman, Brigham and Women's Hospital, Boston, MA) by PstI digestion. Aogen cDNA (1.6 kb) was released from AGTE plasmid (American Type Culture Collection, 18710) by digestion with EcoR1 and HindIII. Radioactive probes were prepared by random priming using the multiprime DNA-labeling system and $\left[\alpha-{ }^{32} \mathrm{P}\right] \mathrm{dCTP}(300 \mathrm{Ci} / \mathrm{mmol}$; Amersham, Arlington Heights, IL). The constancy in amounts of RNA was determined by comparison with $18 \mathrm{~S}$ rRNA.

Western blot of $A T_{1}$ receptors, p53, Bax, and Bcl-2. For immunoblot assay of $\mathrm{AT}_{1}$ receptors, $\mathrm{p} 53$, Bax, and Bcl-2 gene products, myocytes were lysed with 150-200 $\mu$ l of lysis buffer containing the protease inhibitors $2 \mathrm{mM}$ PMSF, $1 \mu \mathrm{g} / \mathrm{ml}$ aprotinin, $5 \mathrm{mM}$ DTT, and $1 \mathrm{mM}$ $\mathrm{Na}_{3} \mathrm{VO}_{4}(5,27)$. Equivalents of $50-120 \mu \mathrm{g}$ of protein were separated by $12 \%$ SDS-PAGE. Proteins were transferred on nitrocellulose filters and exposed to rabbit polyclonal anti-human $\mathrm{AT}_{1}$ receptors (306;
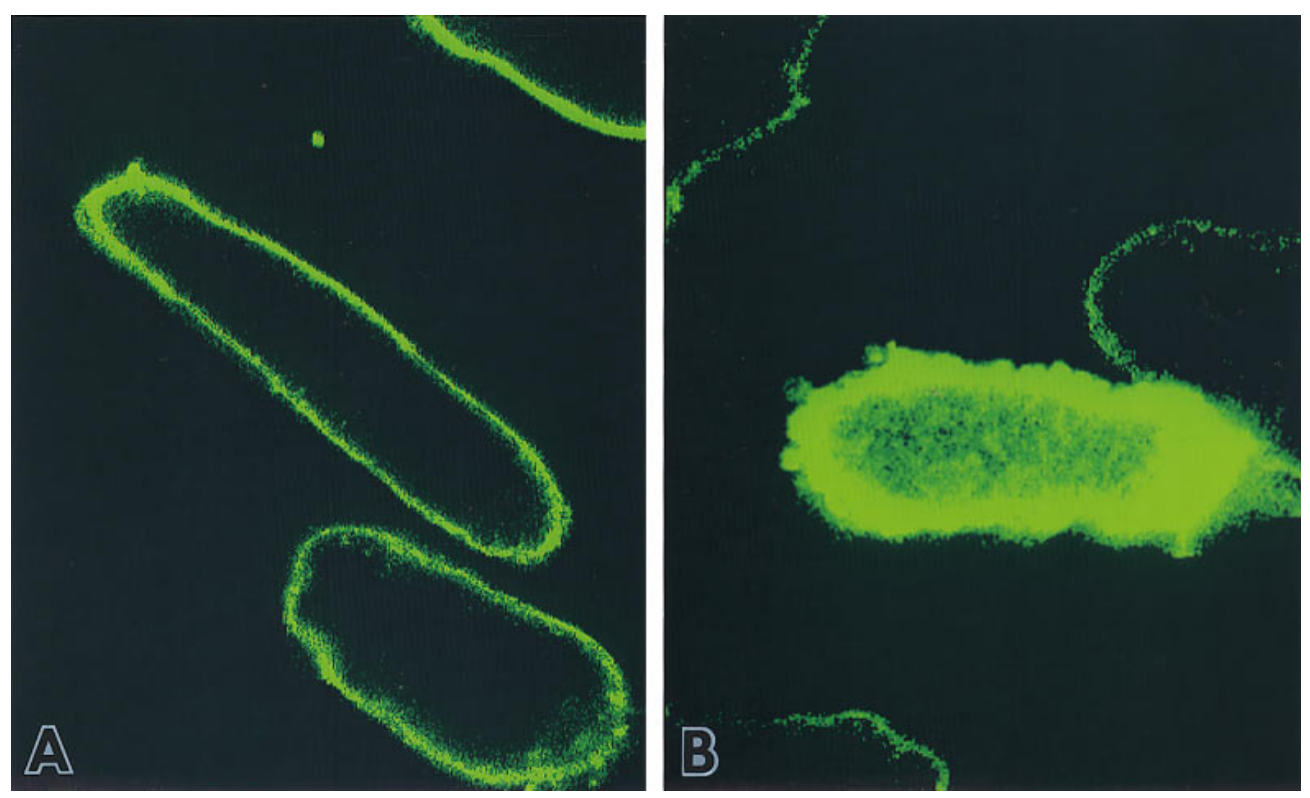

Figure 2. HEDAF labeling of myocytes stretched for $4 \mathrm{~h}$ in SFM. Green fluorescence is restricted to the sarcolemma in intact myocytes $(A)$, whereas HEDAF staining involves the entire cell body in a damaged myocyte $(B)$. Confocal microscopy: $A$ and $B, \times 400$. Quantitative results: $30 \mathrm{~min}$ : nonstretched $=0.75 \pm 0.15 \%(n=4)$; stretched $=0.61 \pm 0.21 \%(n=4)$; $4 \mathrm{~h}$ : nonstretched $=0.52 \pm 0.11 \%$ $(n=4)$; stretched $=0.68 \pm 0.19 \%$ $(n=4) ; 12 \mathrm{~h}$ : nonstretched $=$ $0.70 \pm 0.14 \%(n=4)$; stretched $=0.42 \pm 0.18 \%(n=4) ; 24 \mathrm{~h}$ : nonstretched $=0.59 \pm 0.17 \%$ $(n=4)$; stretched $=0.64 \pm 0.09 \%$ $(n=4)$. 
Santa Cruz Biotechnology), to mouse monoclonal anti-human p53 (PAb240; Santa Cruz Biotechnology), to rabbit polyclonal anti-human Bcl-2 ( $\Delta$ C21; Santa Cruz Biotechnology), and anti-human Bax (P19; Santa Cruz Biotechnology) at a concentration of $1 \mu \mathrm{g} / \mathrm{ml}$ in TBST. Bound antibodies were detected by peroxidase-conjugated antimouse or anti-rabbit IgG and ECL reagents (Amersham). $\mathrm{AT}_{1}$ receptor was detected as a $41-\mathrm{kD}$ band, $\mathrm{p} 53$ as a $53-\mathrm{kD}$ band, $\mathrm{Bcl}-2$ as a $29-\mathrm{kD}$ band, and Bax as a $21-\mathrm{kD}$ band.

Measurement of protein content per cell. Formalin-fixed myocytes were incubated in PBS containing $0.1 \mu \mathrm{g} / \mathrm{ml}$ FITC, $10 \mu \mathrm{g} / \mathrm{ml}$ propidium iodide, and $1 \mathrm{mg} / \mathrm{ml}$ RNase A. Total fluorescence, which corresponded to the protein content per cell (39), was determined by confocal microscopy (MCR-1000; Bio-Rad, Richmond, CA). The intensity of FITC fluorescence was measured by optical sectioning the entire thickness of each myocyte and recording the intensity of fluorescence in each of these sections. These intensities were added to yield the total fluorescence in each myocyte. 50 binucleated myocytes in each culture were measured in this manner. This analysis included four nonstretched and four stretched myocyte cultures at $24 \mathrm{~h}$.

Data analysis. Measurements are means $\pm \mathrm{SD} ; n$ values are listed in the text and correspond to independent cultures. Comparisons between two values were done by Student's $t$ test and multiple comparisons by the Bonferroni method (40). $P<0.05$ was significant.

\section{Results}

Myocyte stretching. Fig. 1 illustrates the effects of an equibiaxial strain of $20 \%$ applied to a substrate in an attempt to transmit this deformation to a culture of adult ventricular myocytes. This device resulted in a $9 \%(P<0.0001)$ increase in sarcomere length from $1.81 \pm 0.02(n=30)$ to $1.98 \pm 0.04 \mu \mathrm{m}(n=$ $40)$. Changes in sarcomere length varied minimally among different preparations, but corresponded to $<50 \%$ of the degree of strain imposed on the distensible membrane. However, sarcomere elongation was uniform in cells distributed in the center and periphery of the substrate, and was not influenced by circumferential or radial orientation. Measurements of 50 myocytes each near the edge and the center of 14 separate cultures showed sarcomere lengths of $1.96 \pm 0.04$ and $2.00 \pm 0.05 \mu \mathrm{m}$, respectively. This small difference, analyzed by paired Student's $t$ test, was not statistically significant $(P=0.13)$. The consequences of stretch on myocyte integrity were established by confocal microscopy after HEDAF labeling (Fig. 2). In each preparation of nonstretched and stretched myocytes, 800-1,000 cells were examined. The percentage of myocytes damaged was not influenced by stretching since similar values were obtained in the absence of sarcomere elongation at the various intervals studied (Fig. 2). In summary, the equibiaxial strain system resulted in moderate and consistent myocyte stretching without affecting membrane integrity.

Stretch and myocyte apoptosis. Myocyte cell death was evaluated by two independent histochemical methods: TdT assay and in situ ligation. This approach was followed because the TdT procedure may overestimate the extent of cell death (33, $41,42)$. The localization of DNA strand breaks evidenced by the TdT technique in nuclei of myocytes stretched for 4 and $24 \mathrm{~h}$ is illustrated by confocal microscopy in Fig. 3. Positive and negative controls for this assay included, respectively, the treatment of cultures with DNase I and the omission of biotin16-dUTP or TdT during the enzymatic reaction $(21,23,25)$. In the former condition, essentially all nuclei were stained, while in the latter no labeling was observed (data not shown).

The identification of apoptotic nuclei in stretched myocytes by in situ ligation of $3^{\prime}$ overhang fragments labeled by
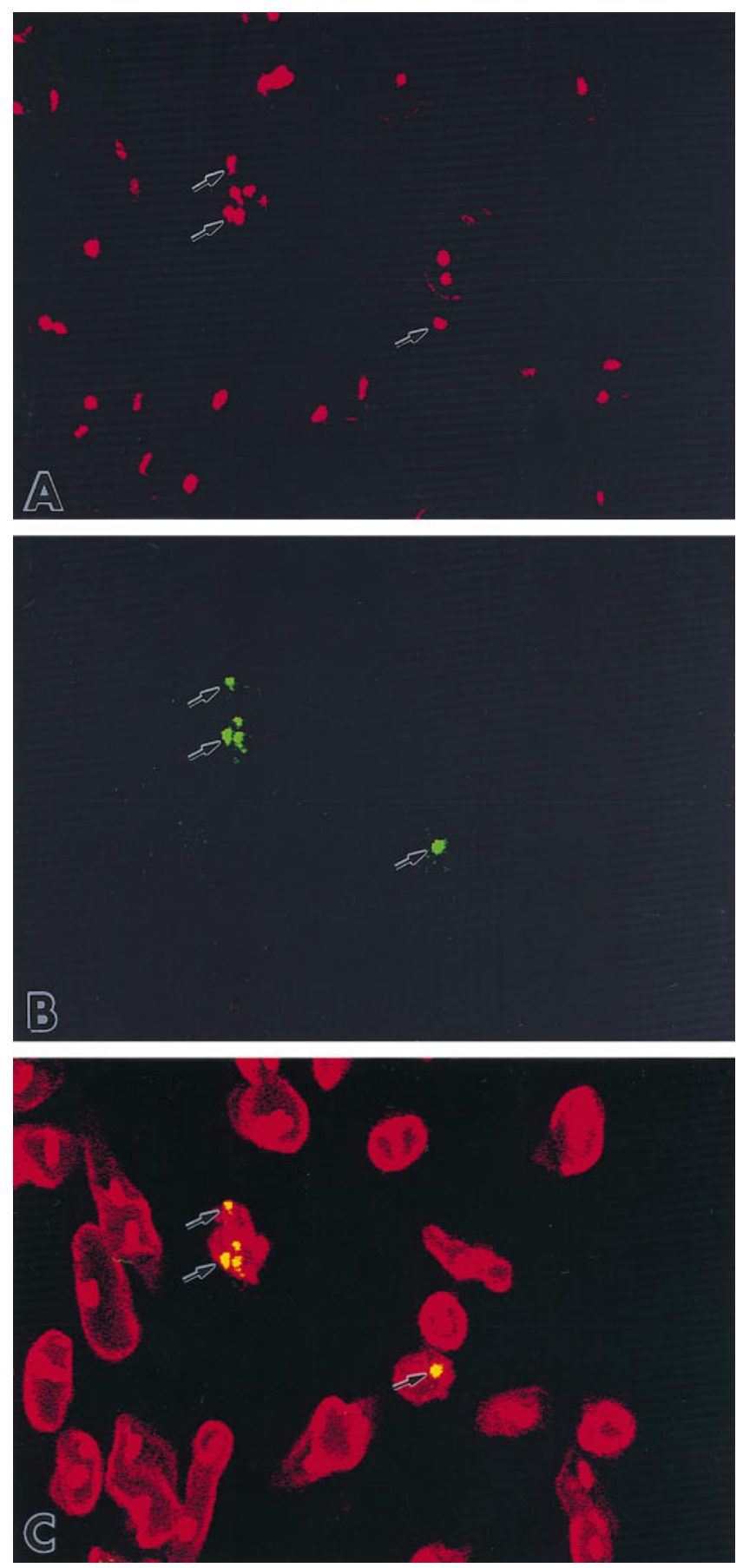

Figure 3. $A$ shows by red fluorescence nuclei stained by propidium iodide and $B$ by green fluorescence DNA strand breaks in nuclei by the TdT assay. $C$ depicts by red fluorescence $\alpha$-sarcomeric actin antibody staining of the myocyte cytoplasm and by yellow fluorescence the combination of propidium iodide and TdT labeling of nuclei. Arrows indicate apoptosis $4 \mathrm{~h}$ after stretching in a mononucleated myocyte and arrowheads indicate two aggregated binucleated myocytes. $D-F$ illustrate by higher magnification two nuclei by the red fluorescence of propidium iodide and the cytoplasm by the red fluorescence of $\alpha$-sarcomeric actin antibody staining $(D)$; a positive TdT reaction in these nuclei is shown by green fluorescence in $E$. The combination of these two stainings of nuclei with the red fluorescence of $\alpha$-sarcomeric actin labeling is depicted in $F$. This myocyte was stretched for 24 h. Confocal microscopy: $A-C, \times 150 ; D-F, \times 750$. 

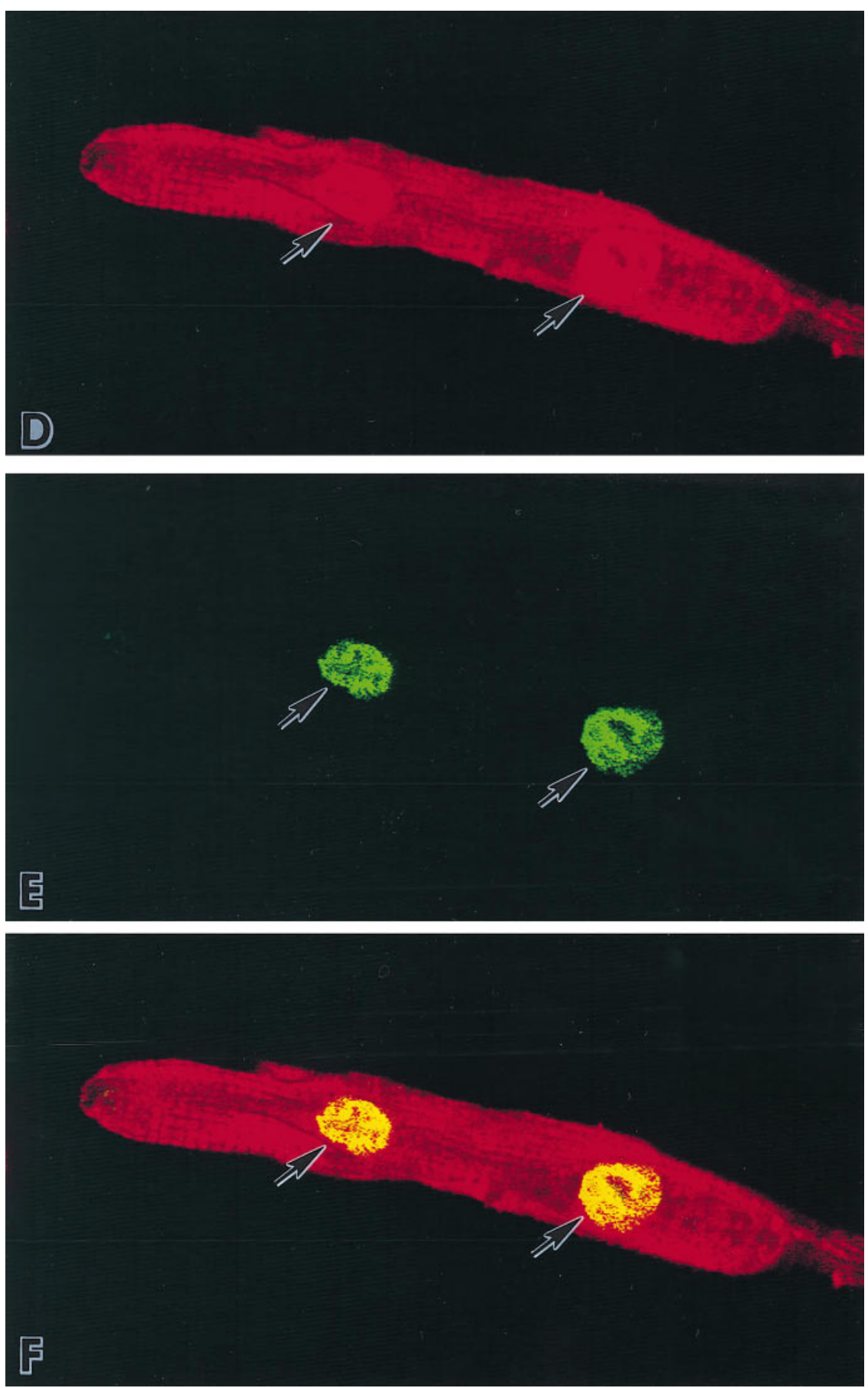

Figure 3 (Continued)

rhodamine is shown in Fig. 4, $A$ and $B$. The specificity of this method to detect DNA strand breaks was documented by the addition of DNase I to the culture. This procedure induced a diffuse positive staining (Fig. $4 \mathrm{C}$ ). Conversely, when DNA ligase was not included, DNA fragmentation was not seen (Fig. $4 \mathrm{D}$ ). Myocyte apoptosis increased after stretch, from 4 to $24 \mathrm{~h}$, with both techniques and the degree of labeling did not appear to differ between the TdT assay and the in situ ligation. However, quantitative data were collected independently with these two methods and compared. Myocyte apoptosis was not observed at 10 and $30 \mathrm{~min}$ and $2 \mathrm{~h}$ after stretching.

At $4 \mathrm{~h}$, TdT labeling involved $1.59 \pm 0.44 \%(n=4)$ of con- trol cells and $7.02 \pm 1.59 \%(n=7)$ of stretched myocytes. Corresponding values at $24 \mathrm{~h}$ were $2.33 \pm 0.55 \%(n=4)$ and $17.6 \pm 4.0 \%(n=5)$. The 4.4- and 7.6-fold increases in apoptosis with stretch at 4 and $24 \mathrm{~h}$ were statistically significant $(P<$ $0.001 ; P<0.001)$. Moreover, from 4 to $24 \mathrm{~h}$ after stretch, there was a 2.5 -fold $(P<0.001)$ increase in apoptosis. These determinations included fluorescence and confocal microscopy. Confocal microscopy allowed also the recognition of chromatin alterations in TdT positive nuclei. The typical half-moon appearance of the apoptotic nucleus is shown (Fig. 5). In nonstretched myocytes at 4 and $24 \mathrm{~h}, 70 \pm 14 \%$ of labeled nuclei had chromatin damage and $30 \pm 14 \%$ did not show morpho- 

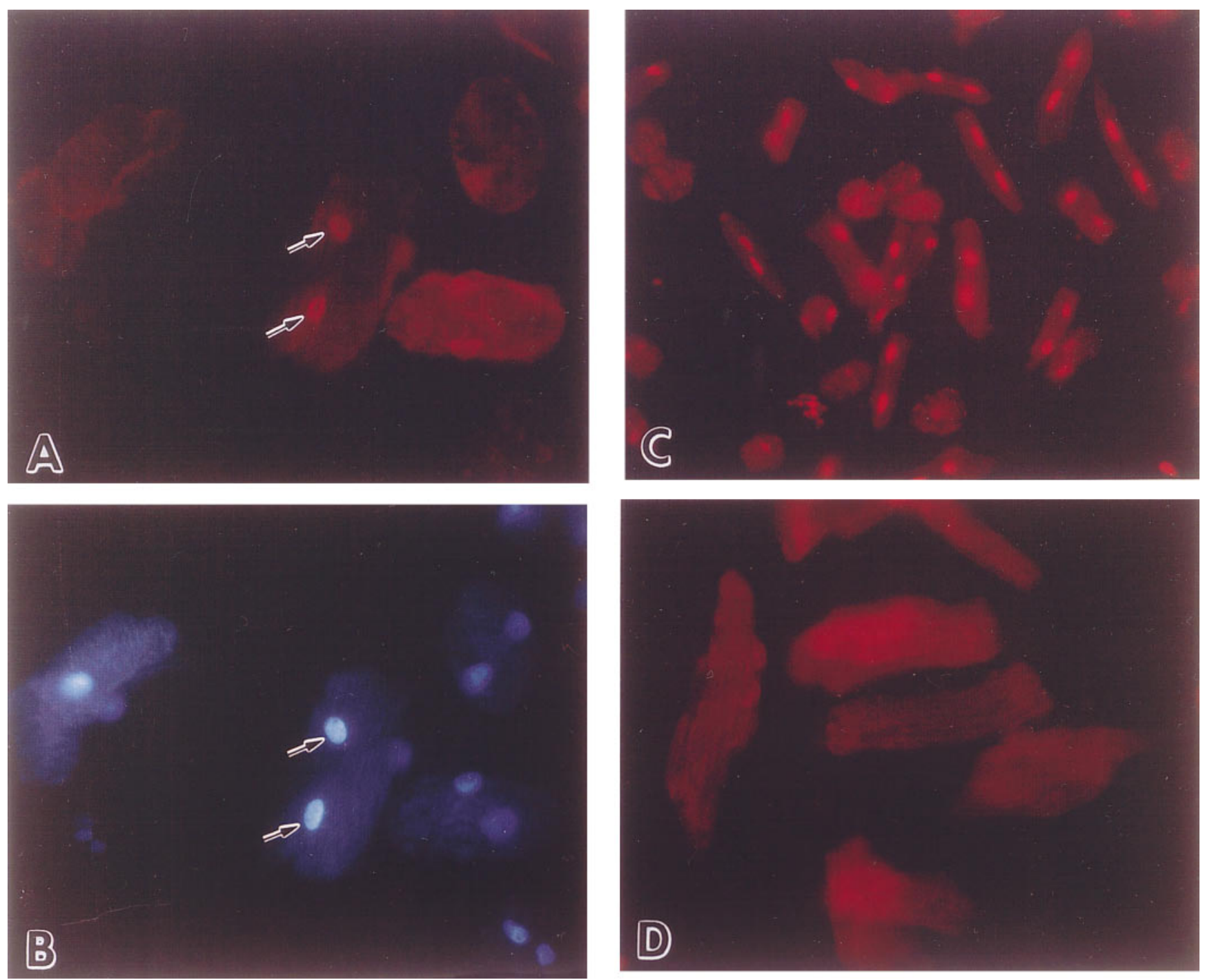

Figure 4. Detection of DNA strand breaks by in situ ligation at $4 \mathrm{~h}$ after stretching. Red fluorescence (arrows) illustrates positive labeling of a binucleated myocyte $(A)$. The localization of nuclei is documented by bisbenzimide staining $(B)$. Myocytes exposed to DNase I (positive control) showed labeling of all nuclei $(C)$. In contrast, the omission of ligase (negative control) resulted in lack of staining of myocyte nuclei $(D)$. $A$, $B$, and $D, \times 400 ; C, \times 200$.

logic changes. However, sampling was small and included a total of 46 myocytes and 86 nuclei. In stretched myocytes at $4 \mathrm{~h}$, $77 \pm 11 \%$ exhibited nuclear modifications and $23 \pm 11 \%$ had normal chromatin appearance. Sampling involved 138 myocytes and 255 nuclei. In myocytes stretched for $24 \mathrm{~h}, 79 \pm 7 \%$ and $21 \pm 7 \%$ showed chromatin abnormalities and intact structure, respectively. Sampling consisted of 255 myocytes and 468 nuclei.

In situ ligation at the earlier time point stained $1.40 \pm 0.25 \%$ $(n=3)$ of nonstretched cells and $6.65 \pm 1.94 \%(n=4)$ of stretched myocytes. At the later period, values of $2.10 \pm 0.40 \%$ $(n=3)$ and $16.6 \pm 3.3 \%(n=3)$ were found in control and stretched myocytes. With this technique, stretching was characterized by a 4.8 -fold $(P<0.001)$ and 7.9 -fold $(P<0.001)$ increase in myocyte apoptosis at 4 and $24 \mathrm{~h}$, respectively. From 4 to $24 \mathrm{~h}$, stretch augmented myocyte apoptosis by 2.5 -fold $(P<$ $0.001)$. Importantly, none of the small differences between
TdT and in situ ligation experiments were statistically significant. In summary, $9 \%$ sarcomere stretching induced apoptosis in myocytes which increased with time.

Stretch and DNA laddering. DNA agarose gel electrophoresis of low molecular weight DNA fragments was evaluated (36). Fig. 6 illustrates that DNA fragments of size equivalent to the mono- and oligonucleosomes were barely detectable in extracts from control myocytes at $4 \mathrm{~h}$. However, they were more visible in nonstretched cells at $24 \mathrm{~h}$. This confirmed that low levels of apoptosis occurred in myocytes in culture in the absence of any intervention. Stretching of sarcomeres was characterized by a marked increase in DNA laddering which was greater at the later than at the earlier interval examined. DNA fragments of $\sim 200,400$, and 600 bp were the most abundant. In summary, $9 \%$ sarcomere stretching produced a DNA electrophoretic pattern typical of apoptosis that increased from 4 to $24 \mathrm{~h}$. 

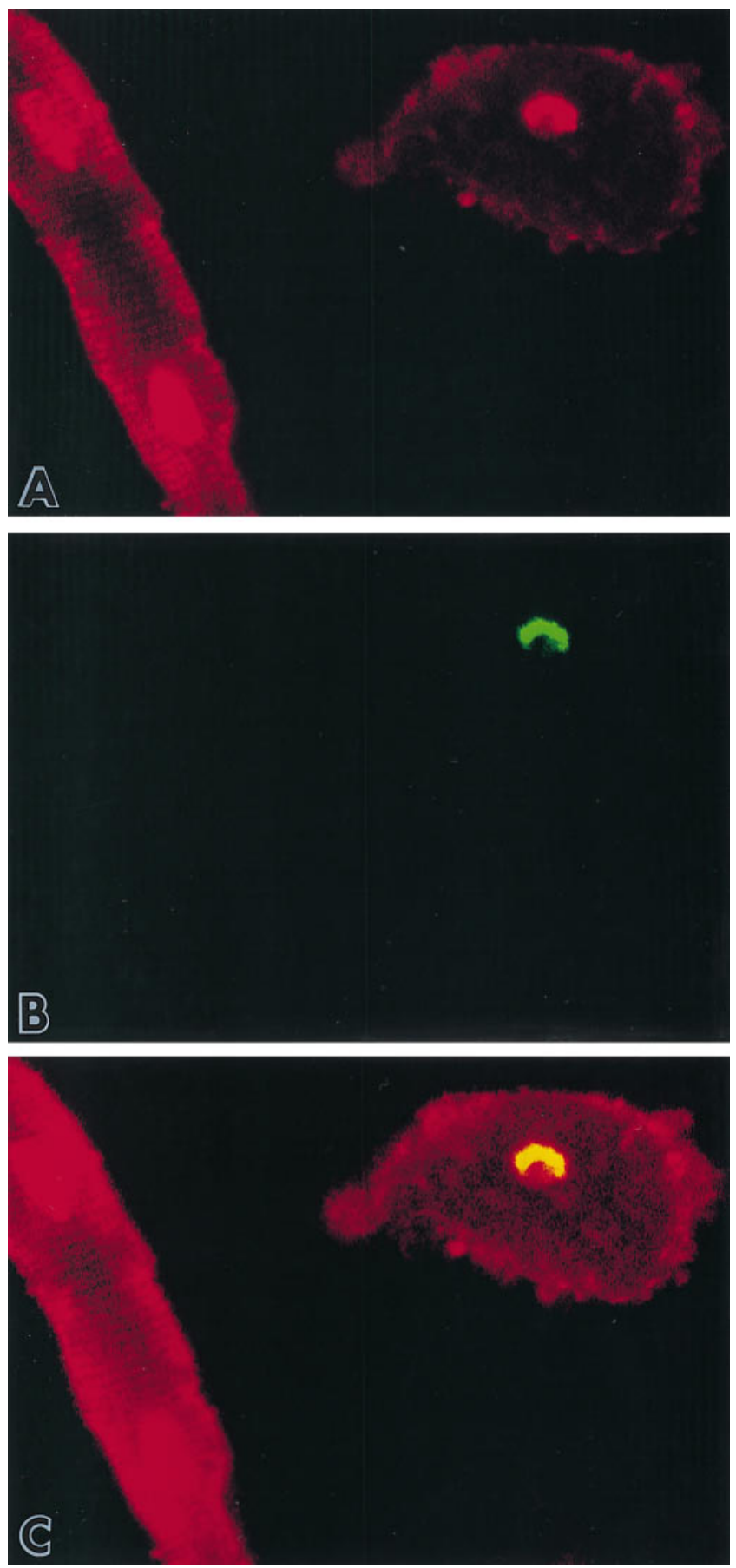

Figure 5. Detection of DNA strand breaks by the TdT assay and confocal microscopy. $A$ shows by red fluorescence of propidium iodide staining a half-moon appearance of a mononucleated myocyte. Green fluorescence in $B$ illustrates positive TdT reaction of the same nucleus depicted in $A$. The peripheral distribution of $\alpha$-sarcomeric actin antibody labeling of the myocyte cytoplasm is also illustrated by red fluorescence in $A$. The combination of these three stainings is depicted in $C$. Confocal microscopy: $A-C, \times 600$.

Stretch and Ang II release. To determine whether sarcomere stretching was associated with the secretion of Ang II in the medium, Ang II was measured in CM collected from cultures of control and stretched myocytes at $10 \mathrm{~min}, 1,4,8,12$, 16, and $20 \mathrm{~h}$. Fig. 7 illustrates that the generation of Ang II in

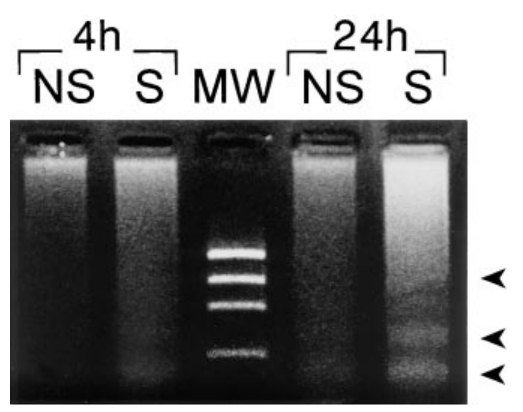

Figure 6. Gel electrophoresis of nonstretched $(N S)$ and stretched $(S)$ myocytes. Arrows indicate bands corresponding to 200 400 , and 600 bp. $M W$, Molecular weight markers. DNA laddering is more apparent in stretched myocytes, particularly at $24 \mathrm{~h}$.

$\mathrm{CM}$ of stretched myocytes peaked at 1 and $20 \mathrm{~h}$. With respect to control cells, there was a 3.6-fold $(P<0.005)$ and 4.4-fold $(P<0.01)$ increase at 1 and $20 \mathrm{~h}$ after stretching, respectively. Ang II quantity in the medium was elevated as early as 10 min after stretching, $103 \%(P<0.05)$, and this tendency persisted at $8 \mathrm{~h}, 73 \%(P<0.05), 12 \mathrm{~h}, 178 \%(P<0.01)$, and $16 \mathrm{~h}, 170 \%$ $(P<0.05)$.

The changes in the percentage of myocytes labeled by Ang II antibody were measured at $30 \mathrm{~min}, 1,4,8,16$, and $24 \mathrm{~h}$ after stretching. A large variability in the number of sites of antibody labeling was observed among cells whether stretched or nonstretched. A myocyte was considered labeled if a minimum of five fluorescent loci was apparent (Fig. 8). Quantitatively, in comparison with nonstretched cells, there was a $55 \%(P<$ $0.0001), 53 \%(P<0.0001)$, and 36\% $(P<0.0001)$ decrease in the magnitude of labeling at $30 \mathrm{~min}, 1 \mathrm{~h}$, and $4 \mathrm{~h}$ after stretch (Fig. 9). In addition, there was an $84 \%(P<0.001)$ increase from $30 \mathrm{~min}$ to $8 \mathrm{~h}$ after stretch, and the value at $8 \mathrm{~h}$ was $18 \%$ $(P<0.05)$ lower than in control myocytes. With respect to baseline, a $28 \%(P<0.05)$ and $20 \%(P<0.05)$ increase in this parameter was noted at 16 and $24 \mathrm{~h}$, respectively. In summary, $9 \%$ sarcomere stretching was associated with the synthesis and secretion of Ang II.

Stretch and p53 DNA binding activity. The promoter of Aogen contains 7 of 10 matches with the consensus sequence

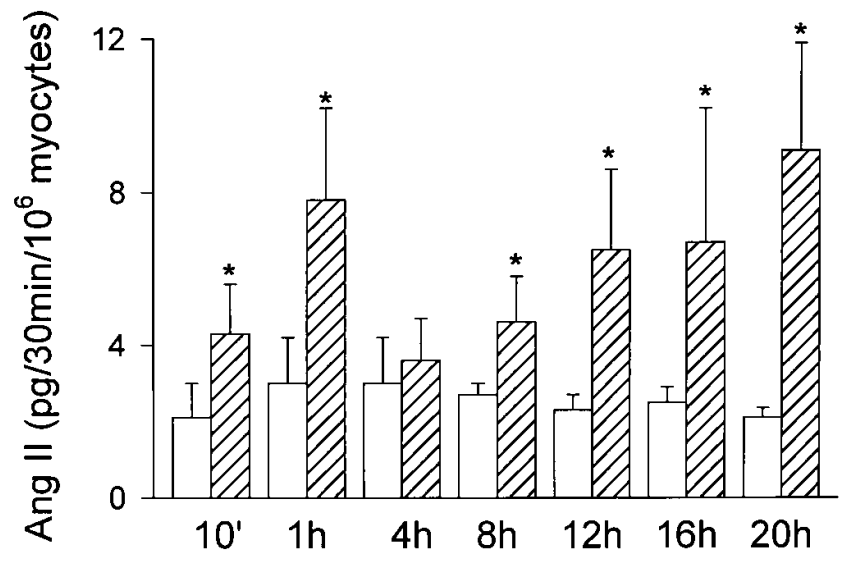

Figure 7. Effects of myocyte stretching on the quantity of Ang II in $\mathrm{CM}$. Results are presented as mean \pm SD. Open bars, Nonstretched myocytes; striped bars, stretched myocytes. *Significant difference from the corresponding value in nonstretched myocytes, $P<0.05$. Nonstretched, $n=3$ at each time point; stretched, $n=5$ at each time point. 

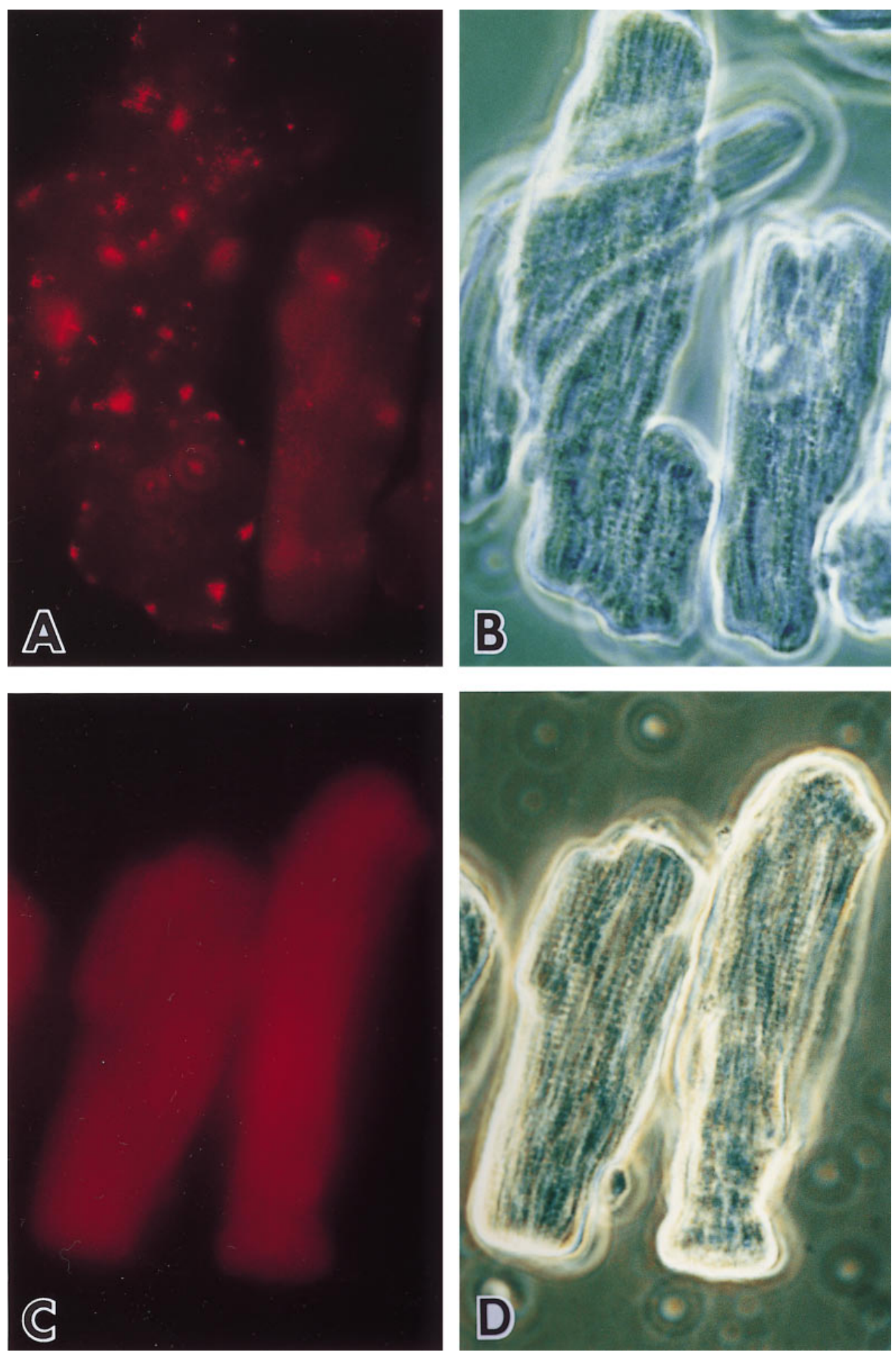

Figure 8. Immunocytochemical detection of Ang II in myocytes stretched for $16 \mathrm{~h}(A) . B$ illustrates by phase-contrast microscopy the same field shown in $A$. Lack of staining in $C$ was obtained after preabsorption of the primary antibody with Ang II. $D$ shows by phase-contrast microscopy the same field illustrated in C. $A-D, \times 700$.

of p53. An oligonucleotide of $25 \mathrm{bp}$ including the ACAAGCC region was radiolabeled and used as a probe in a gel retardation assay. The radioactive probe was incubated with nuclear extracts prepared from control cells and myocytes stretched for $30 \mathrm{~min}, 2,4,8$, and $24 \mathrm{~h}$. One complex with shifted gel mobility was detected at all time points (Fig. $10 A$ ). Moreover, the results obtained at different intervals in nonstretched myocytes are shown in Fig. 10 B. In comparison with nonstretched myocytes, the optical density of the p53 shifted band in stretched cells was elevated at $30 \mathrm{~min}$ and $2 \mathrm{~h}$. DNA binding activity increased further at 4 and remained increased at 8 and $24 \mathrm{~h}$ (Fig. $10 \mathrm{~B}$ ). The validity of the assay was established by subjecting p53-specific bands to competition with an excess of unlabeled self oligonucleotide. Moreover, the position of the p53 band was compared with that detected in SV-T2 cells (Fig. $10 \mathrm{~A}$ ). Subsequently, incubation of nuclear extracts with two 


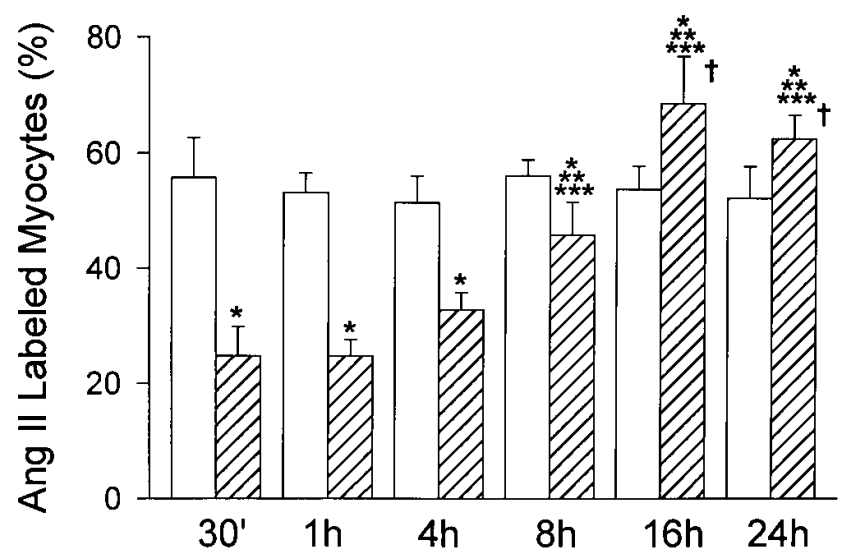

Figure 9. Effects of stretch on the percentage of myocytes labeled by Ang II. Results are presented as mean \pm SD. Open bars, Nonstretched myocytes; striped bars, stretched myocytes. *Difference from the corresponding value in nonstretched myocytes, $P<0.05$. ** Difference from the corresponding value in stretched myocytes at $30 \mathrm{~min}, P<$ 0.05 . ***Difference from the corresponding value in stretched myocytes at $1 \mathrm{~h}, P<0.05$. ${ }^{\dagger}$ Difference from the corresponding values in stretched myocytes at $8 \mathrm{~h}, P<0.05$. Nonstretched, $n=3$ at each time point; Stretched, $n=5$ in each time point.

different anti-p53 antibodies failed to reveal mobility-shifted complexes (Fig. 11), confirming the specificity of this gel retardation assay.

In a manner comparable to Aogen, the $\mathrm{AT}_{1}$ receptor promoter shares 7 of 10 matches with the consensus sequence of p53. Thus, an oligonucleotide probe of $25 \mathrm{bp}$ was prepared. This probe that contained the ACATGCC sequence was endlabeled and used in a gel shift analysis (Fig. 10 C). With respect to nonstretched cells (Fig. $10 \mathrm{D}$ ), stretched myocytes showed one shifted complex that increased 30 min after the imposition of stretch. The optical density of the shifted band was also increased at 2, 4, 8, and $24 \mathrm{~h}$ (Fig. $10 \mathrm{D}$ ). The specificity of the assay was established as described above for Aogen and is illustrated in Figs. $10 C$ and 11.

Since the bax promoter possesses a perfect p53 binding site and three imperfect ones (28), a segment of this promoter, containing 46-bp sequence, was radiolabeled and used as a probe. When nuclear extracts from stretched myocytes (Fig. $10 \mathrm{E}$ ) and nonstretched myocytes (not shown) were incubated with the DNA probe, a complex with shifted gel mobility was detected. p53 DNA binding activity was increased in stretched myocytes at $30 \mathrm{~min}, 2,4,8$, and $24 \mathrm{~h}$ (Fig. $10 \mathrm{E}$ ). Controls for the gel mobility assay are shown in Fig. $10 E$ and 11 . In this case, a mutated form of bax was used to confirm further the specificity of the assay (Fig. 11). Finally, consistency in protein loading, lack of protein degradation, and uniformity in the relative purity of nuclear extracts at various time points after stretch are shown in Fig. $10 \mathrm{~F}$. The optical density of the actin band was significantly reduced (see Fig. 13 for comparison) and was consistent throughout, confirming that the level of cytoplasmic contamination affected in a similar manner the nuclear preparations. In summary, $9 \%$ sarcomere stretching was coupled with enhanced p53 binding to the promoter of Aogen, $\mathrm{AT}_{1}$ receptor, and bax genes.
Ang II and p53 DNA binding activity. To establish whether the changes in DNA binding of p53 described in Figs. 10 and 11 were influenced by stretch-mediated release of Ang II from myocytes, nonstretched myocytes were treated with Ang II at $10^{-9} \mathrm{M}$ in the presence of protease inhibitors and the activation of p53-dependent genes was examined. The concentration of Ang II was 125-fold higher than that detected by RIA after stretch. Ang II stimulation for a period of $4 \mathrm{~h}$ (the last addition of Ang II was 30 min earlier) resulted in a marked increase in p53 binding to the promoter of Aogen. The optical density of the shifted complex decreased significantly at 24 h, i.e., $20.5 \mathrm{~h}$ after the last administration of Ang II (Fig. $12 \mathrm{~A}$ ). However, the intensity of the p53 band at this later time point was still higher than at baseline (Fig. $12 \mathrm{~A}$, fourth lane). The 25 -fold increase at $4 \mathrm{~h}$ and the 4 -fold increase at $24 \mathrm{~h}$ after Ang II stimulation were statistically significant $(P<0.0001 ; P<0.0001)$. Similarly, the $78 \%$ reduction in this parameter from 4 to $24 \mathrm{~h}$ was significant $(P<0.005)$. Additionally, p53 binding to the promoter of $\mathrm{AT}_{1}$ receptor increased 32-fold $(P<0.0001)$ at $4 \mathrm{~h}$ after Ang II. A subsequent decrease, 93\% ( $P<0.0001)$, was noted at $24 \mathrm{~h}$ (Fig. $12 \mathrm{~B}$ ). Finally, Ang II stimulation enhanced p53 binding to the consensus sequence in the bax promoter at $4 \mathrm{~h}, 14$-fold $(P<0.0001)$, and the p53 band at $24 \mathrm{~h},-41 \%(P<$ 0.0001), was reduced (Fig. $12 C$ ). In summary, Ang II stimulation was characterized by enhanced p53 binding to the promoter of Aogen, $\mathrm{AT}_{1}$ receptor, and bax genes in nonstretched myocytes.

Stretch, Aogen, AT $T_{1}$-receptor, p53, Bcl-2, and Bax expression. Fig. $13 A$ illustrates the effects of stretch on the expression of Aogen in myocytes by Northern blot analysis. In comparison with nonstretched control myocytes, sarcomere elongation resulted in an increase in the quantity of Aogen mRNA at $1 \mathrm{~h}$. At $8 \mathrm{~h}$, the expression of Aogen was still elevated, although the amount of Aogen mRNA was lower than at the earlier time point. At $24 \mathrm{~h}$ the transcription of this gene was less than at 1 and $8 \mathrm{~h}$. Densitometric data were obtained by dividing the signals for Aogen mRNA by the signals for $18 \mathrm{~S}$ rRNA. However, the increases in Aogen expression at these three intervals after stretch (Fig. $13 A$ ) were statistically significant $(P<0.0001 ; P<0.0001 ; P<0.0001)$.

The changes in $\mathrm{AT}_{1}$ receptor protein with stretch were determined by Western blot (Fig. $13 B$ ). In comparison with nonstretched cells at 4,8 , and $24 \mathrm{~h}$, stretched myocytes showed a 25\% (NS), $138 \%(P<0.0001)$, and $200 \%(P<0.0001)$ increase in the quantity of this protein. In addition, the consequences of stretch on p53 expression are illustrated in Fig. 13 C. p53 protein increased progressively after stretch, from 4 to $24 \mathrm{~h}$. Densitometrically there was a $138 \%$ increase at $4 \mathrm{~h}$ $(P<0.05), 444 \%$ at $8 \mathrm{~h}(P<0.0001)$, and $1,171 \%$ at $24 \mathrm{~h}(P<$ $0.0001)$.

Since p53 is a transcriptional modulator of the bcl- 2 and bax genes (28), the quantity of these proteins was determined by Western blot in nonstretched and stretched myocytes. Fig. $13 D$ illustrates that Bax protein in stretched myocytes increased $47 \%(P<0.0001)$ at $2 \mathrm{~h}$, returned to baseline at $8 \mathrm{~h}$, increased again $44 \%(P<0.01)$ at $16 \mathrm{~h}$, and returned to control values at $24 \mathrm{~h}$. In contrast, the amount of Bcl-2 (Fig. $13 \mathrm{E}$ ) decreased 28\% $(P<0.0001), 57 \%(P<0.0001), 75 \%(P<$ $0.0001)$, and $53 \%(P<0.0001)$ at $2,8,16$, and $24 \mathrm{~h}$, respectively. These changes resulted in a reduction of the Bcl-2-toBax ratio in stretched myocytes. In summary, $9 \%$ sarcomere stretching enhanced the expression of Aogen, $\mathrm{AT}_{1}$ receptors, 
A
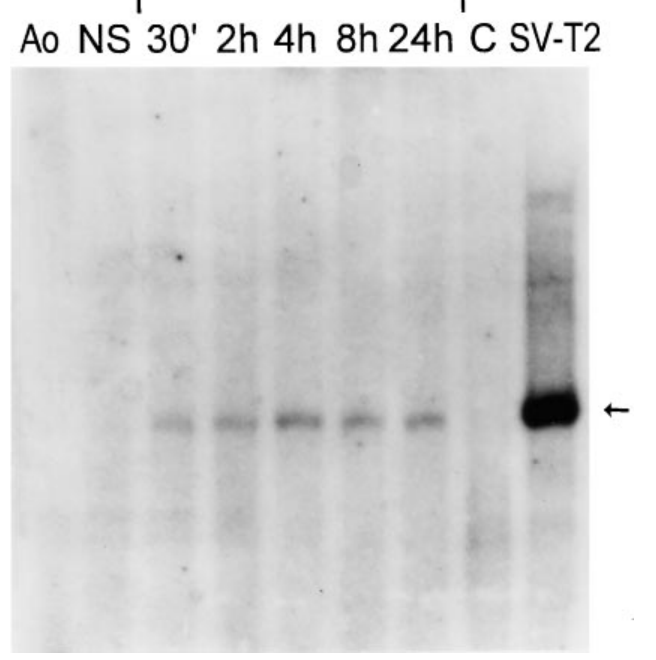

C

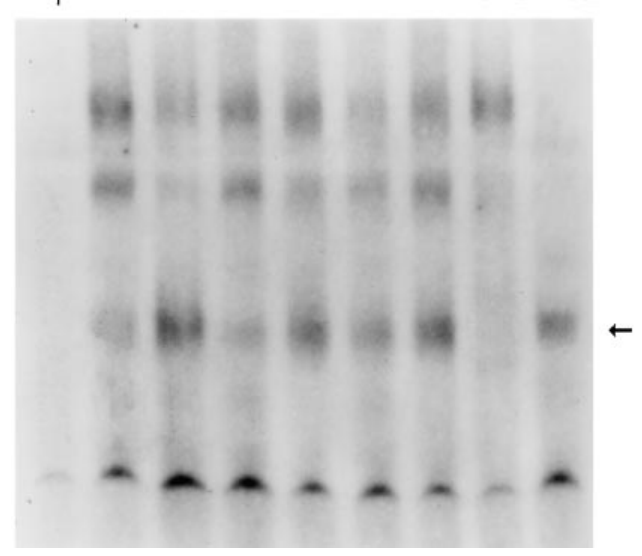

E Bax C Ab NS 30' 2h 4h 8h 24h SV-T2

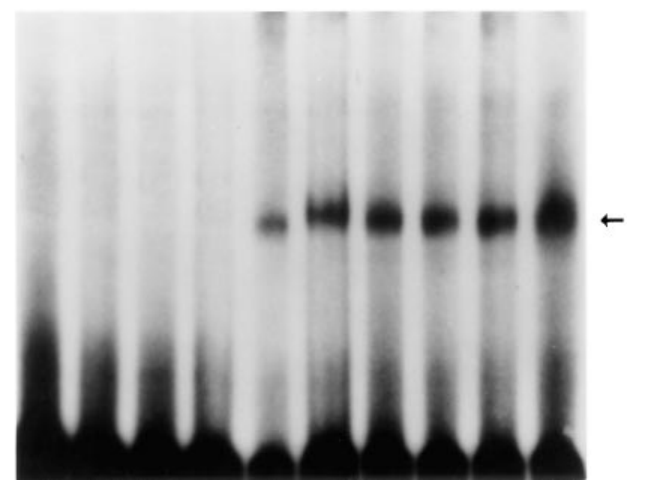
$\mathrm{AT}_{1} \mathrm{NS} 30^{\prime} 2 \mathrm{~h} 4 \mathrm{~h} 8 \mathrm{~h} 24 \mathrm{~h}$ C SV-T2

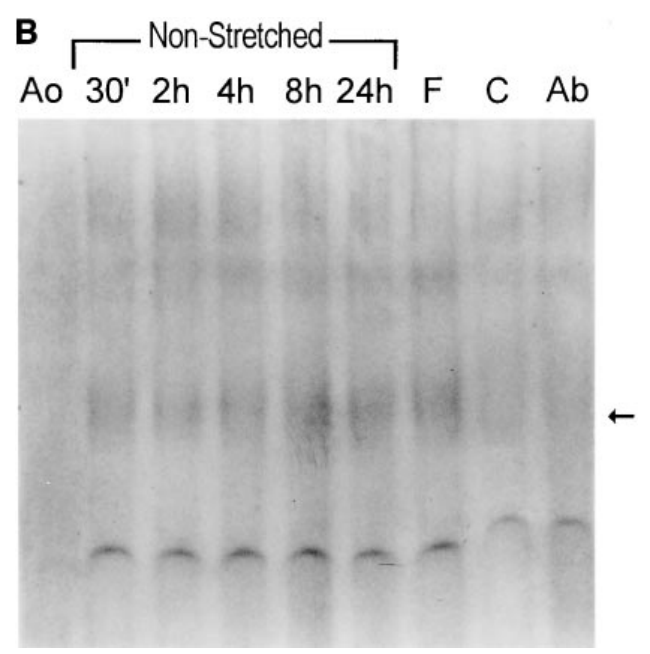

D $\Gamma^{\text {Non-Stretched }}$ $\mathrm{AT}_{1} \mathrm{C}$ Ab 30' 2h 4h 8h 24h F SV-T2

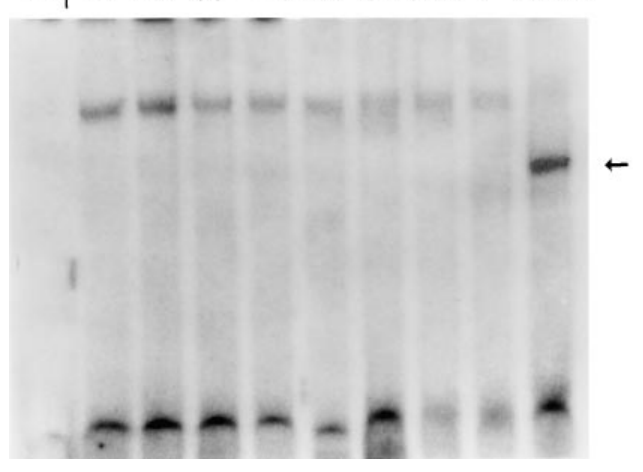

$\mathbf{F}$

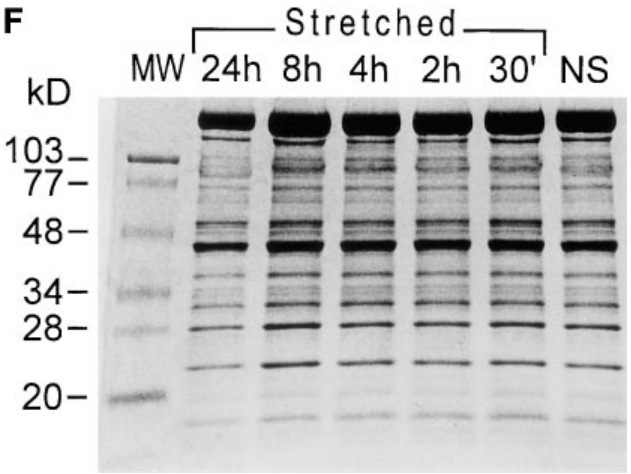

Figure 10. (A) Gel mobility assay showing the interaction of p53 with its consensus sequence in the Aogen promoter. Nuclear extracts were obtained from nonstretched myocytes $(N S)$ at $24 \mathrm{~h}$ and myocytes stretched for $30 \mathrm{~min}, 2,4,8$, and $24 \mathrm{~h}$. p53-specific band ( $4 \mathrm{~h}$ after stretching) was subject to competition with an excess of unlabeled self oligonucleotide, competitor $(C)$. $A o$, Aogen probe in the absence of nuclear extract. $S V-T 2$, nuclear extract from SV-T2 cells. The arrow indicates the position of the p53 shifted band. (B) Gel mobility assay showing the interaction of p53 with its consensus sequence in the Aogen promoter. Nuclear extracts were obtained from freshly isolated myocytes $(F)$ and nonstretched myocytes kept in culture for $30 \mathrm{~min}, 2,4,8$, and $24 \mathrm{~h}$. p53-specific band (4 h in culture) was subject to competition with an excess of unlabeled self oligonucleotide, competitor $(C)$. $A b$, Nuclear extract from nonstretched myocytes at $4 \mathrm{~h}$ incubated with p53 antibody PAb240. Ao, Aogen probe in the absence of nuclear extracts. The arrow indicates the position of the p53 shifted band. Optical density results in nonstretched and stretched myocytes were: 30 min: nonstretched $=4.0 \pm 1.3$, $n=5$, stretched $=24 \pm 12, n=5$, $P<0.005 ; 2$ h: nonstretched $=$ $4.4 \pm 1.6, n=5$, stretched $=$ $46 \pm 8, n=5, P<0.001$; 4 h: nonstretched $=5.2 \pm 1.6, n=5$, stretched $=84 \pm 16, n=5, P<$ $0.0001 ; 8 \mathrm{~h}$ : nonstretched $=$ 4.8 $\pm 1.3, n=5$, stretched $=$ $51 \pm 17, n=5, P<0.0001 ; 24 \mathrm{~h}:$ nonstretched $=4.4 \pm 1.2, n=5$, stretched $=73 \pm 20, n=5, P<$ 0.0001 . (C) Gel mobility assay showing the interaction of $\mathrm{p} 53$ with its consensus sequence in the $\mathrm{AT}_{1}$ promoter. Nuclear extracts were obtained from nonstretched myocytes $(N S)$ at $24 \mathrm{~h}$ and myocytes stretched for 30 $\min , 2,4,8$, and 24 h. p53-specific band ( $4 \mathrm{~h}$ after stretching) was subject to competition with an excess of unlabeled self oligonucleotide, competitor $(C) . A T_{1}, \mathrm{AT}_{1}$ probe in the absence of nuclear extract. $S V$-T2, Nuclear extract from SV-T2 cells. The arrow indicates the position of the p53 shifted band. $(D)$ Gel mobility assay showing the interaction of $\mathrm{p} 53$ with its consensus sequence in the $\mathrm{AT}_{1}$ promoter. Nuclear extracts were obtained from freshly isolated myocytes $(F)$ and nonstretched myocytes kept in culture for $30 \mathrm{~min}, 2,4,8$, and $24 \mathrm{~h}$. p53-specific band ( $4 \mathrm{~h}$ in culture) was subject to competition with an excess of unlabeled self oligonucleotide, competitor $(C)$. $A b$, Nuclear extract from nonstretched myocytes at $4 \mathrm{~h}$ incubated with p53 antibody PAb240. $A T_{1}$, $\mathrm{AT}_{1}$ probe in the absence of nuclear extract. $S V-T 2$, nuclear extract from SV-T2 cells. The arrow indicates the position of the p53 shifted band. Optical density results in nonstretched and stretched myocytes were: 30 min: nonstretched $=7.0 \pm 2.3, n=5$, stretched $=67 \pm 25, n=5, P<$ $0.0001 ; 2$ h: nonstretched $=4.6 \pm 1.9, n=5$, stretched $=28 \pm 8, n=5, P<0.0001 ; 4$ h: nonstretched $=4.4 \pm 2.0, n=5$, stretched $=45 \pm 16, n=5$, $P<0.0001 ; 8$ h: nonstretched $=4.8 \pm 2.6, n=5$, stretched $=52 \pm 12, n=5, P<0.0001 ; 24$ h: nonstretched $=4.8 \pm 2.4, n=5$, stretched $=65 \pm 17$, $n=5, P<0.0001$. (E) Gel mobility assay showing the interaction of $\mathrm{p} 53$ with its consensus sequence in the bax promoter. Nuclear extracts were 
A
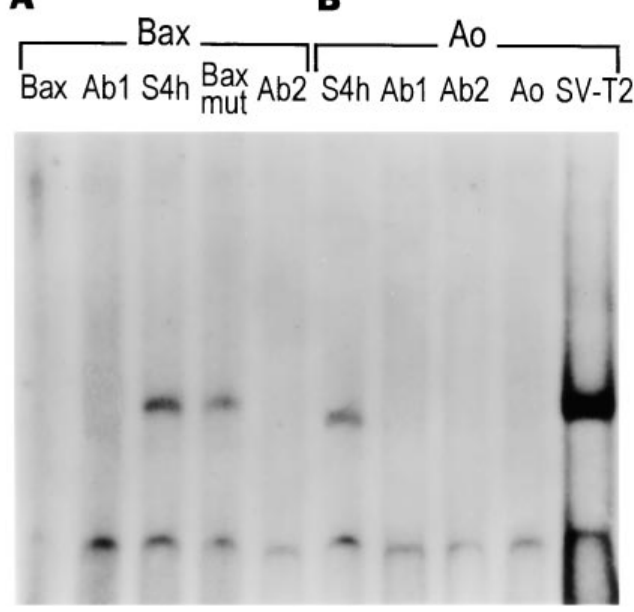

C

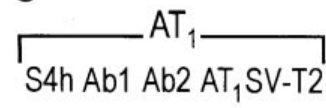

Figure 11. (A) Gel mobility assay showing the interaction of p53 with its consensus sequence in the bax promoter. Nuclear extracts were obtained from stretched myocytes at $4 \mathrm{~h}(S 4 h)$. p53-specific band was subject to competition with p53 antibodies PAb240 (Ab1) and PAb122 (Ab2). Bax mut, Unlabeled mutated Bax probe. Bax, Bax probe in the absence of nuclear extract. $S V-T 2$, Nuclear extract from SV-T2 cells. The arrow indicates the position of p53 shifted band. Addition of p53 antibodies opposed the appearance of a p53 shifted complex in both cases.

(B) Gel mobility assay showing the interaction of p53 with its consensus sequence in the Aogen promoter. Nuclear extracts were obtained from stretched myocytes at $4 \mathrm{~h}(S 4 h)$. p53-specific band was subject to competition with p53 antibodies PAb240 ( $A b 1)$ and PAb122 ( $A b 2)$. Ao, Aogen probe in the absence of nuclear extract. $S V-T 2$, Nuclear extract from SV-T2 cells. The arrow indicates the position of p53 shifted band. Addition of p53 antibodies opposed the ap-

pearance of a p53 shifted complex in both cases. $(C)$ Gel mobility assay showing the interaction of p53 with its consensus sequence in the AT 1 promoter. Nuclear extracts were obtained from stretched myocytes at $4 \mathrm{~h}(S 4 h)$. p53-specific band was subject to competition with p53 antibodies PAb240 (Ab1) and PAb122 (Ab2). $A T_{1}, \mathrm{AT}_{1}$ probe in the absence of nuclear extract. $S V$ - $T 2$, Nuclear extract from SV-T2 cells. The arrow indicates the position of p53 shifted band. Addition of p53 antibodies opposed the appearance of a p53 shifted complex in both cases.

p53, and Bax and decreased the expression of Bcl-2 in the cells.

Stretch, $A T_{1}$ antagonist, and apoptosis. To determine whether ligand binding to surface $\mathrm{AT}_{1}$ receptors was involved in stretch-mediated apoptosis, myocytes were exposed to losartan and, 30 min later, sarcomere elongation was induced. Control myocytes were similarly treated, but stretch was not applied. The selective $\mathrm{AT}_{1}$ blocker, losartan, prevented programmed cell death measured by the TdT assay at both 4 (nonstretched: $1.63 \pm 0.42 \%, n=4$; stretched: $1.36 \pm 0.57 \%, n=$ 4; not significant) and $24 \mathrm{~h}$ (nonstretched: $2.18 \pm 0.81 \%, n=4$; stretched: $2.02 \pm 0.47, n=4$; not significant) after stretching. Moreover, a gel mobility assay was performed using nuclear extracts from control and stretched myocytes exposed to losartan. The 4-h interval after stretching was examined because p53 binding activity in the Aogen and bax promoters was elevated at this time. As illustrated in Fig. 14, the $\mathrm{AT}_{1}$ receptor blocker reduced the optical density of the p53 shifted band. This determination was repeated three times. In summary, losartan inhibited stretching-induced apoptosis in myocytes and $\mathrm{p} 53$ binding activity.

p53 and activation of $A T_{1}$ and Aogen genes. We have shown previously that infection of adult rat ventricular myocytes with a replication-deficient adenoviral vector containing wild-type human p53 was characterized by enhanced expression of Bax, Aogen, and $\mathrm{AT}_{1}$ receptor (27). p53 DNA binding activity in these experiments was assessed by oligonucleotide probes for Aogen and $\mathrm{AT}_{1}$ identical to those used in this study. Moreover, Fig. $11 A$ illustrated that the addition of a mutated form of bax, characterized by the substitution of two nucleotides in the perfect consensus motif for p53 binding, had no effect on the interaction between wild bax and p53. This indicates that the sequence of the bax oligonucleotide used was critical for the detection of p53 binding activity in rat myocytes. Similar results have been obtained in dog ventricular myocytes (43). In this early study, the same bax oligonucleotide was shown to bind to p53 in SV-T2 cells which overexpress p53. The specificity of the shifted complex in this cell system was demonstrated by using the mutated form of bax and anti-p53 antibody. On this basis, SV-T2 cells were used here to document whether the imperfect p53 consensus sequences in the $\mathrm{AT}_{1}$ and Aogen promoters were capable of competing with the $\mathrm{p} 53$ binding site of bax and between themselves. Such an approach was used to determine whether the sequences selected were critical for the responsiveness of the $\mathrm{AT}_{1}$ and Aogen genes to $\mathrm{p} 53$.

Fig. $15 A$ illustrates that, in the presence of nuclear extract from SV-T2 cells, the $\mathrm{AT}_{1}$ oligonucleotide resulted in the formation of two shifted complexes (second lane) which were

\section{Figure 10 legend (Continued)}

obtained from nonstretched myocytes $(N S)$ at $24 \mathrm{~h}$ and myocytes stretched for $30 \mathrm{~min}, 2,4,8$, and $24 \mathrm{~h}$. p53-specific band (4 h after stretching) was subject to competition with an excess of unlabeled self oligonucleotide, competitor $(C)$, and with p53 antibody PAb240 $(A b)$. Bax, Bax probe in the absence of nuclear extract. $S V-T 2$, Nuclear extract from SV-T2 cells. The arrow indicates the position of the p53 shifted band. Optical density results in nonstretched and stretched myocytes were: $30 \mathrm{~min}$ : nonstretched $=2.0 \pm 1.1, n=5$, stretched $=45 \pm 13, n=5, P<0.0001$; $2 \mathrm{~h}$ : nonstretched $=2.7 \pm 1.2, n=5$, stretched $=72 \pm 7, n=5, P<0.0001 ; 4$ h: nonstretched $=1.7 \pm 0.7, n=5$, stretched $=84 \pm 19, n=5, P<$ $0.0001 ; 8$ h: nonstretched $=2.2 \pm 0.9, n=5$, stretched $=73 \pm 20, n=5, P<0.0001 ;$ and 24 h: nonstretched $=2.3 \pm 0.4, n=5$, stretched $=70 \pm 19$, $n=5, P<0.0001$. $(F)$ The pattern of proteins corresponding to the nuclear preparations used for mobility shift assays is illustrated by Coomassie blue staining. The actin band, $42 \mathrm{kD}$, is markedly reduced and rather uniform in all samples. Protein degradation is not apparent. $M W$, Molecular weight markers. 

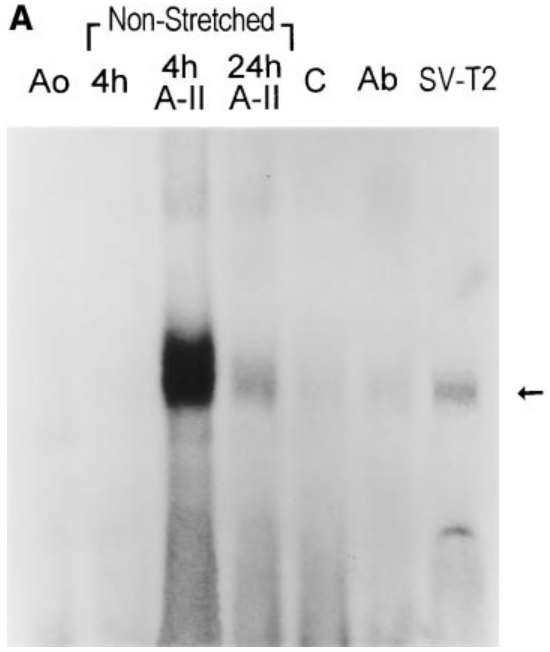

B

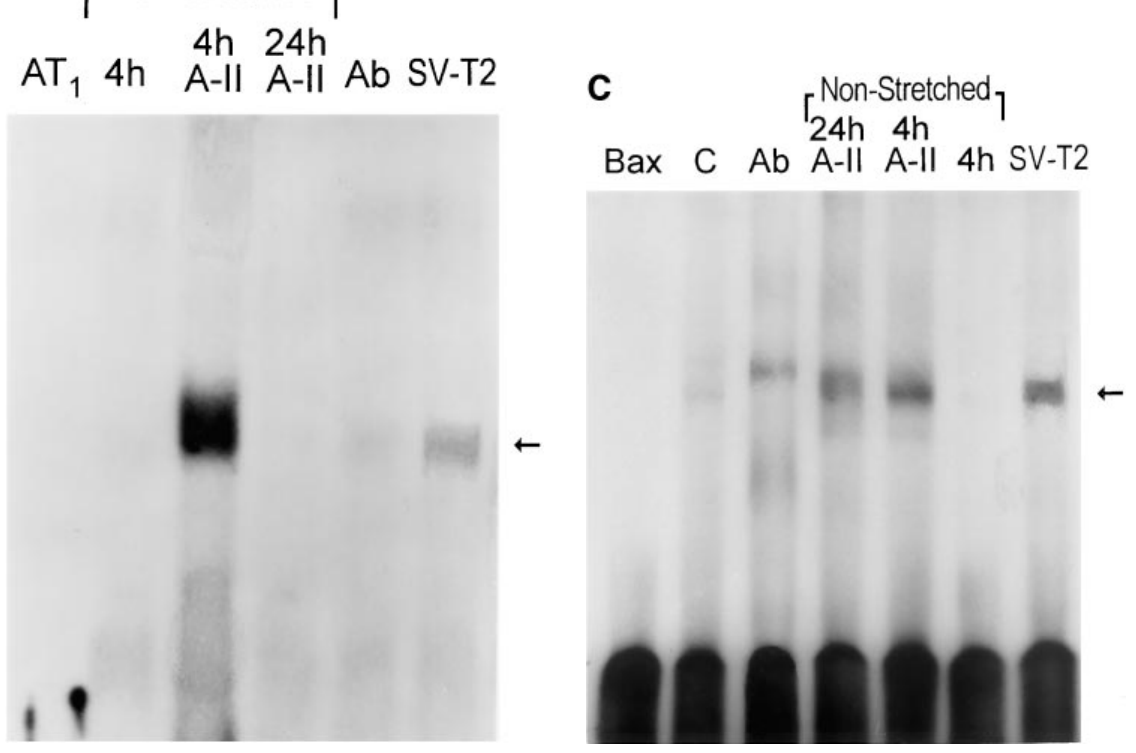

Figure 12. (A) Gel mobility assay showing the interaction of p53 with its consensus sequence in the Aogen promoter. Nuclear extracts were obtained from nonstretched myocytes kept in culture for $4 \mathrm{~h}$ and from nonstretched myocytes stimulated with Ang II ( $A$ - $I I)$ for 4 and 24 h. p53-specific band at $4 \mathrm{~h}$ after Ang II was subject to competition with an excess of unlabeled self oligonucleotide, competitor $(C)$, and with the p53 antibody PAb122 $(A b)$. Ao, Aogen probe in the absence of nuclear extract. $S V$-T2, Nuclear extract from SV-T2 cells. The arrow indicates the position of the p53 shifted band. Optical density values were: nonstretched, $4 \mathrm{~h}=4 \pm 2(n=4), 24 \mathrm{~h}=5 \pm 2(n=4)$; nonstretched + Ang II, $4 \mathrm{~h}=101 \pm 25(n=4), 24 \mathrm{~h}=22 \pm 6(n=4)$. $(B)$ Gel mobility assay showing the interaction of p53 with its consensus sequence in the AT promoter. Nuclear extracts were obtained from nonstretched myocytes kept in culture for $4 \mathrm{~h}$ and from nonstretched myocytes stimulated with Ang II ( $A-I I)$ for 4 and $24 \mathrm{~h}$. p53-specific band at $4 \mathrm{~h}$ after Ang II was subject to competition with the p53 antibody PAb122 $(A b)$. $A T_{1}$, AT 1 probe in the absence of nuclear extract. $S V$-T2, Nuclear extract from SV-T2 cells. The arrow indicates the position of the p53 shifted band. Optical density values were: nonstretched, $4 \mathrm{~h}=3 \pm 1(n=4), 24 \mathrm{~h}=4 \pm 1(n=4)$; nonstretched + Ang II, $4 \mathrm{~h}=95 \pm 16(n=4), 24 \mathrm{~h}=7 \pm 5(n=4)$. $(C)$ Gel mobility assay showing the interaction of p53 with its consensus sequence in the bax promoter. Nuclear extracts were obtained from nonstretched myocytes kept in culture for $4 \mathrm{~h}$ and from nonstretched myocytes stimulated with Ang II ( $A$ - $I I)$ for 4 and $24 \mathrm{~h}$. p53-specific band at $4 \mathrm{~h}$ after Ang II was subject to competition with an excess of unlabeled self oligonucleotide, competitor $(C)$, and with the p53 antibody PAb122 $(A b) . B a x$, Bax probe in the absence of nuclear extract. $S V$-T2, nuclear extract from SV-T2 cells. The arrow indicates the position of the p53 shifted band. Optical density values were: nonstretched, $4 \mathrm{~h}=5 \pm 2(n=4), 24 \mathrm{~h}=4 \pm 1(n=4) ;$ nonstretched + Ang II, $4 \mathrm{~h}=71 \pm 8(n=4)$, $24 \mathrm{~h}=42 \pm 6(n=4)$.

markedly attenuated by competition with the unlabeled $\mathrm{AT}_{1}$ probe (third lane). Preincubation with unlabeled bax (fourth lane) and unlabeled Aogen (fifth lane) significantly reduced the p53 bands. Similarly, the single shifted complex obtained with the Aogen probe (Fig. 15 B, second lane) essentially disappeared with preexposure of nuclear extracts to unlabeled Aogen (Fig. 15 B, fourth lane). Preincubation with unlabeled bax (Fig. 15 B, third lane) and unlabeled $\mathrm{AT}_{1}$ (Fig. 15 B, fifth lane) decreased the intensity of the $\mathrm{p} 53$ complex. In summary, the oligonucleotide sequences used were critical for the binding of p53 to bax, Aogen, and $\mathrm{AT}_{1}$ receptor genes.

Stretch, ANF expression, and myocyte protein content. Northern blot analysis of nonstretched and stretched myocytes showed that ANF mRNA increased at 30 min after sarcomere elongation. However, the quantity of ANF mRNA decreased markedly at 4 and $8 \mathrm{~h}$, returning to baseline value at $24 \mathrm{~h}$ after stretch (Fig. 16). Densitometric data were as follows: nonstretched at $30 \mathrm{~min}=1.7 \pm 0.4(n=3)$, and $24 \mathrm{~h}=1.4 \pm 0.9(n=$ $3)$; stretched at $30 \mathrm{~min}=151 \pm 38(n=3), 4 \mathrm{~h}=28 \pm 5(n=3)$, $8 \mathrm{~h}=16 \pm 4(n=3)$, and $24 \mathrm{~h}=3 \pm 2(n=3)$. The 89 -fold increase in ANF mRNA at $30 \mathrm{~min}$ in stretched myocytes was statistically significant $(P<0.0001)$.

To establish whether stretch for $24 \mathrm{~h}$ was associated with an increase in myocyte volume, the amount of protein per cell was determined by confocal microscopy after staining with fluorescein isothiocyanate. This parameter was found to be comparable in nonstretched and stretched myocytes. Total pixel intensity per cell was $185,000 \pm 9,000$ in control myocytes $(n=$ 4 separate cultures) and 182,000 $\pm 13,500$ in myocytes exposed to sarcomere elongation for $24 \mathrm{~h}$ ( $n=4$ separate cultures). This small difference was not statistically significant. In summary, myocyte stretch resulted in an acute transient increase in ANF expression and in no cellular hypertrophy at $24 \mathrm{~h}$.

\section{Discussion}

The results of this study indicate that moderate sarcomere stretching of adult ventricular myocytes was associated with the release of Ang II and the activation of p53 which were followed by programmed cell death shortly after the imposition of the mechanical stimulus. Stretch increased p53 binding to the promoter of Aogen, $\mathrm{AT}_{1}$ receptor, and Bax as well as the cellular formation of Ang II, suggesting that this transcription factor may modulate not only the local RAS but also potentiate the susceptibility of myocytes to undergo apoptosis. The $\mathrm{AT}_{1}$ blocker losartan inhibited apoptosis and p53 DNA bind- 
A S1h N1h N8h S8h S24hN24h
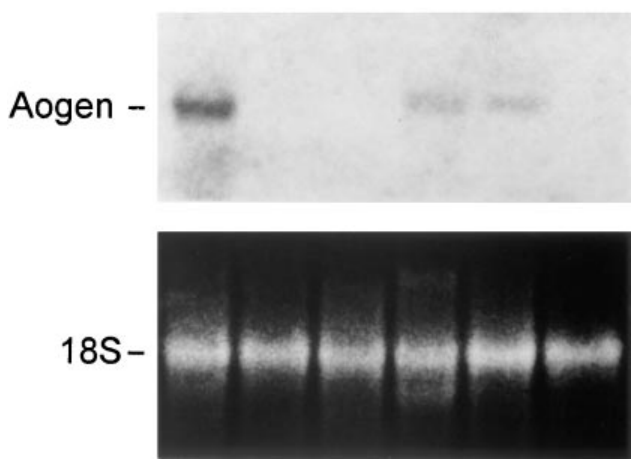

B
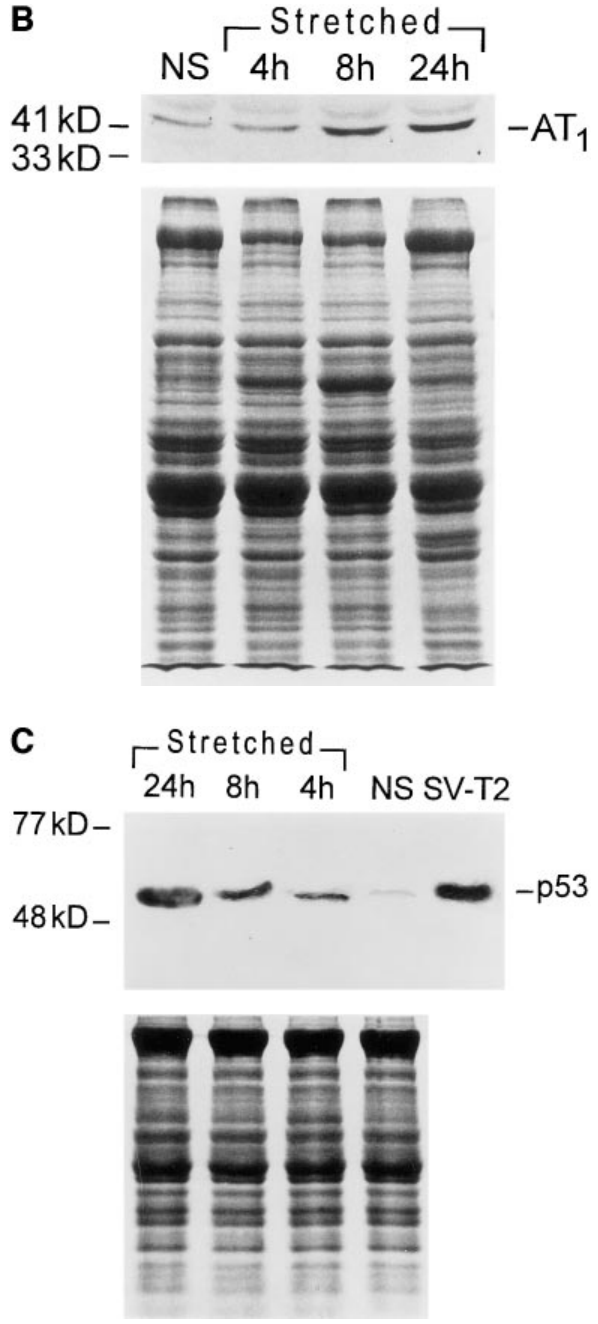

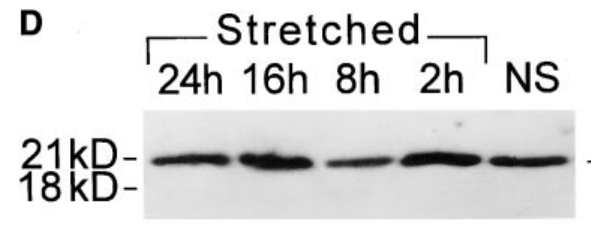

-Bax

Figure 13. (A) Detection of Aogen mRNA by Northern blot analysis (top) in nonstretched $(N)$ myocytes at

1,8 , and $24 \mathrm{~h}$, and stretched $(S)$ myocytes at 1,8 , and $24 \mathrm{~h}$. Equal loading conditions are indicated in the bottom panel by ethidium bromide staining of $18 \mathrm{~S}$ rRNA. Densitometric data were obtained by dividing the signals for Aogen mRNA by the signals for $18 \mathrm{~S}$ rRNA. Optical density values were: nonstretched, $1 \mathrm{~h}=1 \pm 1(n=3)$, $8 \mathrm{~h}=2 \pm 2(n=3), 24 \mathrm{~h}=$ $2 \pm 1(n=3)$; stretched, $1 \mathrm{~h}=$ $147 \pm 17(n=3), 8 \mathrm{~h}=53 \pm 15$ $(n=3), 24 \mathrm{~h}=29 \pm 6(n=3)$.

(B) Detection by Western blot of $\mathrm{AT}_{1}$ receptor protein (top) in nonstretched (NS) myocytes at $24 \mathrm{~h}$ and stretched myocytes at 4,8 , and $24 \mathrm{~h}$. Loading of proteins is illustrated by Coomassie blue staining (bottom). Optical density values were: nonstretched, $4 \mathrm{~h}=24 \pm 4, n=4$, $8 \mathrm{~h}=26 \pm 3, n=4,24 \mathrm{~h}=$ $24 \pm 5, n=4$; stretched, $4 \mathrm{~h}=$ $30 \pm 6, n=4,8$ h: $62 \pm 11, n=$ 4,24 h: $72 \pm 7, n=4$. $(C)$ Detection by Western blot of $\mathrm{p} 53$ protein (top) in nonstretched $(N S)$ myocytes at $24 \mathrm{~h}$ and stretched myocytes at 4,8 , and $24 \mathrm{~h}$. Proteins from SV-T2 cells were used as a positive control. Protein loading consisted of $120 \mu \mathrm{g}$ for myocytes and $30 \mu \mathrm{g}$ for SV-T2 cells. Loading of proteins is illustrated by Coomassie blue staining (bottom). Optical density values were: $4 \mathrm{~h}$, nonstretched $=8 \pm 6, n=4$; stretched $=19 \pm 7, n=4 ; 8 \mathrm{~h}$, nonstretched $=$ $9 \pm 4, n=4$; stretched $=49 \pm 13, n=4 ; 24 \mathrm{~h}$, nonstretched $=7 \pm 4, n=4$; stretched $=89 \pm 10$, $n=4$. (D) Detection by Western blot of Bax protein (top) in nonstretched (NS) myocytes at $24 \mathrm{~h}$ and stretched myocytes at $2,8,16$, and $24 \mathrm{~h}$. Loading of proteins is illustrated by Coomassie blue staining (bottom). Optical density values were: $2 \mathrm{~h}$, nonstretched $=57 \pm 8, n=7$; stretched $=84 \pm 12, n=5 ; 8 \mathrm{~h}$, nonstretched $=55 \pm 7, n=5$; stretched $=61 \pm 13, n=8 ; 16 \mathrm{~h}$, nonstretched $=57 \pm 11, n=5 ;$ stretched $=82 \pm 15, n=7 ; 24 \mathrm{~h}$, nonstretched $=54 \pm 9, n=5$; stretched $=64 \pm 8, n=5$. (E) Detection by Western blot of Bcl-2 protein (top) in nonstretched $(N S)$ and stretched myocytes at 2, 8, 16, and $24 \mathrm{~h}$. Loading of proteins is illustrated by Coomassie blue staining (bottom). Optical density values were: $2 \mathrm{~h}$, nonstretched $=$ $96 \pm 9, n=7$; stretched $=69 \pm 12, n=7 ; 8 \mathrm{~h}$, nonstretched $=101 \pm 12, n=5$; stretched $=$ $43 \pm 19, n=6 ; 16 \mathrm{~h}$, nonstretched $=94 \pm 18, n=5$; stretched $=24 \pm 11, n=5 ; 24 \mathrm{~h}$, nonstretched $=103 \pm 16, n=5$; stretched $=48 \pm 10, n=6$. ing activity, raising the possibility that the $\mathrm{AT}_{1}$ effector pathway may be critical in regulating p53 function and cell death. Ligand binding to surface $\mathrm{AT}_{1}$ receptors may be linked to the phosphorylation of the tumor suppressor protein $\mathrm{p} 53$ that may influence myocyte death by upregulating the synthesis and secretion of Ang II and by decreasing the Bcl-2-to-Bax protein ratio in the cell.

Stretch and myocyte apoptosis. Mechanical stimuli have multiple effects on myocytes in vivo $(1,2)$ and in vitro (9). Physical forces cause rapid induction of immediate early genes $(8,11)$, and expression of skeletal $\alpha$-actin, ANF, and $\beta$-myosin heavy chain (10). They activate a number of second messenger pathways $(9,12)$ and lead to myocyte hypertrophy $(18)$. Cells perceive the external load and this recognition has been associated with the release of Ang II which functions as the initial activator of myocyte growth (18). The growth-promoting influ- 
A

Ao S4h S4h Ab SV-T2

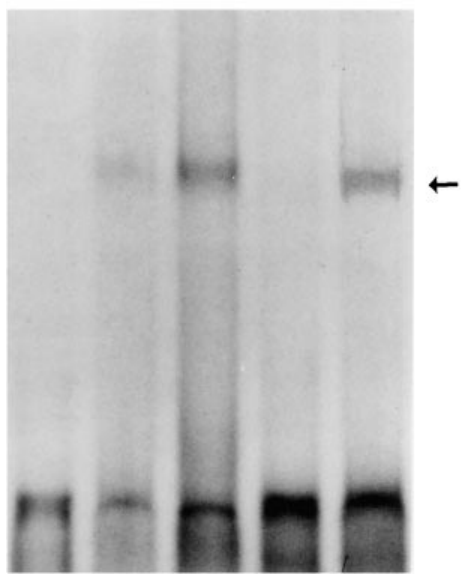

B

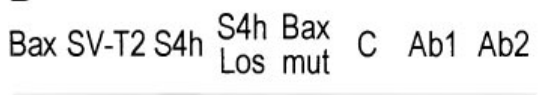

ence of Ang II has been shown in neonatal (18) and adult (44) myocytes, although a more attenuated response has been claimed in the matured fully differentiated cell (44). More recently, stretch has been implicated in the stimulation of programmed myocyte cell death (21) and Ang II in the nanomolar
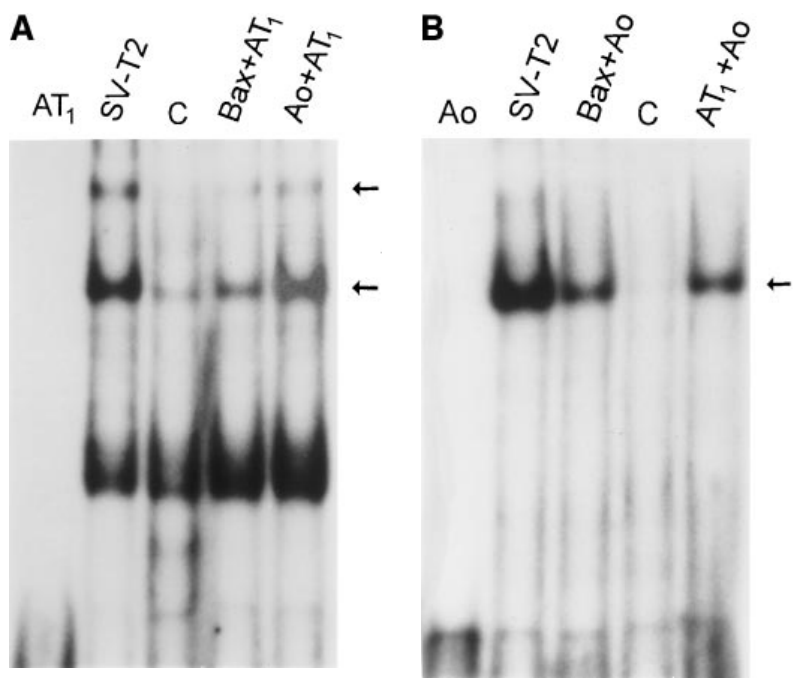

Figure 15. (A) Gel mobility assay showing the interaction of p53 with its consensus sequence in the $\mathrm{AT}_{1}$ promoter. Nuclear extracts were obtained from SV-T2 cells. p53-specific bands were subject to competition with an excess of unlabeled self oligonucleotide, competitor $(C)$, with unlabeled Bax probe $\left(B a x+A T_{1}\right)$ and with unlabeled Aogen probe $\left(A o+A T_{1}\right) . \mathrm{AT}_{1}$ corresponds to the $\mathrm{AT}_{1}$ probe in the absence of nuclear extract. Arrows indicate the position of the $\mathrm{p} 53$ shifted bands. (B) Gel mobility assay showing the interaction of p53 with its consensus sequence in the Aogen $(A o$ ) promoter. Nuclear extracts were obtained from SV-T2 cells. p53-specific band was subject to competition with an excess of unlabeled self oligonucleotide, competitor $(C)$, with unlabeled Bax probe $(B a x+A o)$ and with unlabeled $\mathrm{AT}_{1}$ probe $\left(A T_{1}+A o\right)$. Ao corresponds to the Aogen probe in the absence of nuclear extract. The arrow indicates the position of the p53 shifted band. range has been seen to trigger myocyte apoptosis $(19,20)$. The current results provide the first documentation that sarcomere elongation of adult ventricular myocytes was coupled with the release of Ang II and the activation of the endogenous cell death pathway. Apoptosis was not observed up to $2 \mathrm{~h}$ after stretch, but involved $7 \%$ of myocytes at $4 \mathrm{~h}$ and $17 \%$ at $24 \mathrm{~h}$. Abnormal increases in preload on the myocardium in vivo and in vitro are characterized by scattered cell death, architectural rearrangement of myocytes, mural thinning, and cavitary dilation (21-24, 45-47). These observations suggest that mechanical forces generated in vivo in the pathologic heart may lead to wall restructuring through the release of Ang II, apoptosis, and side by side translocation of cells. However, understanding of the dual role of stretch on cell growth and cell death is complex. The question why apoptosis or cellular hypertrophy occurs in certain cells more than in others is important but remains to be answered.

Double-strand DNA cleavage in myocyte nuclei was de-
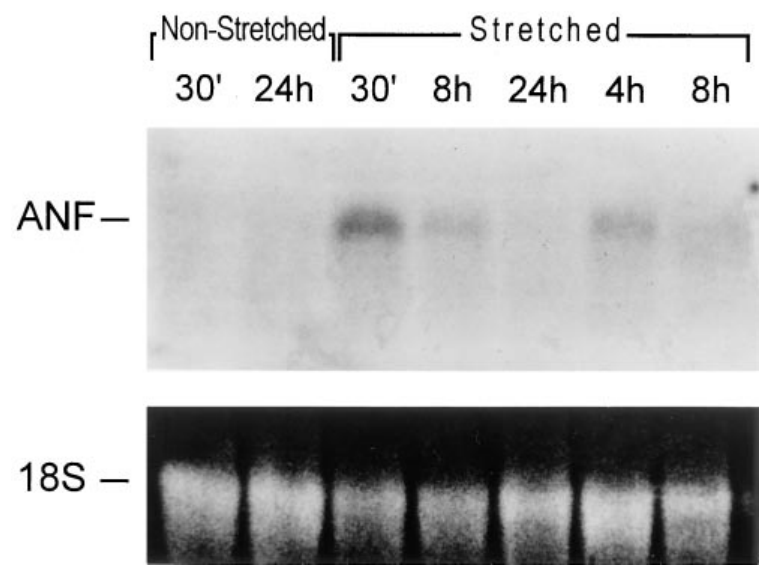

Figure 16. Detection of ANF mRNA by Northern blot analysis (top) in nonstretched and stretched myocytes. Equal loading conditions are indicated in the bottom panel by ethidium bromide staining of $18 \mathrm{~S}$ rRNA. 
tected by the TdT assay and the in situ ligation technique. This approach was introduced because the TdT reaction may overestimate the degree of apoptosis $(33,41,42)$. A large variability in the extent of myocyte cell death has been reported by the TUNEL test and values up to $35 \%$ have been claimed in the failing human myocardium $(3,5,25,48)$. Measurements of apoptosis here were essentially comparable with the two methodologies since similar data were obtained with TdT and in situ ligation. Additionally, as previously performed (5), evaluations of cell death by TdT labeling were confirmed by the analysis of chromatin alterations by confocal microscopy. However, the in situ ligation procedure identifies doublestrand DNA cleavage with single base $3^{\prime}$ overhangs which occur exclusively during apoptosis (33). Blunt-ended products in DNA damage may be present in advanced stages of cell necrosis but are not stained by this technique. The presence of single base $3^{\prime}$ overhangs in nuclei has been linked to the activation of $\mathrm{Ca}^{2+}$-dependent DNase I (33) that is implicated in Ang IImediated myocyte apoptosis (19). The nearly threefold increase in myocyte apoptosis from 4 to $24 \mathrm{~h}$ after stretching most likely reflects the upregulation in proapoptotic gene products and in the density of $\mathrm{AT}_{1}$ receptors that together may have contributed to enhance the proficiency of cells to die during this period.

Stretch and Ang II. Neonatal ventricular myocytes contain Ang II that is released by mechanical stimuli (16). Our observations indicate that a similar phenomenon occurred in adult cells. Ang II antibody labeling of the myocyte cytoplasm decreased at $30 \mathrm{~min}$ and 1 and $4 \mathrm{~h}$ after stretching but a pattern similar to nonstretched cells was detected at $8 \mathrm{~h}$ and values greater than baseline were seen at 16 and $24 \mathrm{~h}$. Moreover, the concentration of Ang II in the CM was elevated at $10 \mathrm{~min}$ and $1 \mathrm{~h}$, decreased at $4 \mathrm{~h}$, and increased progressively from 8 to $20 \mathrm{~h}$. These results are consistent with an immediate release of Ang II and the chronic synthesis and secretion of this peptide from stretched myocytes. Although the release of Ang II from myocyte stores may be the immediate consequence of stretching, more difficult is the identification of the mechanism which activates chronically the cellular RAS, sustaining the formation of Ang II. In neonatal myocytes in vitro as well as in this study on adult ventricular myocytes, stretch is characterized by enhanced transcription of Aogen mRNA and this response has been considered critical for the continuous local production of Ang II (18). A similar effect has been observed by cyclical stretch (49). However, the molecular bases of the stimulation of the myocyte RAS and Aogen in particular were not identified $(18,49)$.

Stretch and 553 activation. The tumor suppressor protein p53 can produce cell cycle arrest and facilitate apoptosis, but these actions are not interdependent (50). In response to DNA damage, there is an accumulation of endogenous p53 that exerts its growth-suppressive effect by preventing proliferation (51). p53 can also activate transcription when it binds to specific DNA sequences in the promoter region of various genes $(50,51)$. To date, multiple genes containing p53 binding sites have been identified. In the heart, p53 transcripts appear to decrease rapidly during early postnatal development, becoming almost undetectable in the adult fully differentiated myocytes (52). However, the levels of p53 mRNA and protein may not change in cells, whereas both DNA binding and transcriptional activity may increase severalfold (53).

The results of this study demonstrate that rat ventricular myocytes subjected to sarcomere stretching were characterized by enhanced p53 binding to the promoter of Aogen, $\mathrm{AT}_{1}$ receptor, and the proapoptotic gene bax. These observations suggest that the initial release of Ang II from myocytes and the stimulation of the $\mathrm{AT}_{1}$ receptor effector pathway were the mediators of the upregulation in $\mathrm{p} 53$ function. This contention is consistent with the capacity of the $\mathrm{AT}_{1}$ receptor blocker losartan to attenuate markedly stretch-mediated p53 DNA binding activity. Conversely, Ang II increased p53 binding to Aogen, $\mathrm{AT}_{1}$, and bax promoters in nonstretched myocytes. The carboxy terminal of the $\mathrm{p} 53$ protein possesses two distinct regulatory sites which are phosphorylated, respectively, by protein kinase $\mathrm{C}$ and casein kinase II (54). Sarcomere stretching and the secretion of Ang II may be coupled with protein kinase C translocation (20) and phosphorylation of p53. This may activate the cellular RAS and the continuous generation of Ang II. The relationship between physical forces, on the one hand, and the local RAS and p53, on the other, is consonant with the ability of losartan to prevent stretch-mediated apoptosis.

Binding of $\mathrm{p} 53$ to Aogen, $\mathrm{AT}_{1}$, and bax promoters in stretched myocytes increased as early as $30 \mathrm{~min}$ after the imposition of the mechanical stimulus and remained elevated up to $24 \mathrm{~h}$. Such a response indicates that stretch led to a consistent transactivation of these genes because only small variations in p53 DNA binding activity were noted at the various intervals. The induction of the Aogen, $\mathrm{AT}_{1}$ receptor, and bax genes by p53 with sarcomere elongation was coupled with increased Aogen mRNA level and $\mathrm{AT}_{1}$ receptor and Bax proteins. The decrease in Bcl-2 expression was also indicative of p53 activation. Changes in the proportion of members of the Bcl-2 protein family suggest that the sensitivity of myocytes to undergo apoptosis was increased (55). Conversely, the activation of p53 per se and the alterations in the relative quantities of p53inducible genes cannot be interpreted as indices of apoptosis (28). Upregulation of Bax or attenuation of Bcl-2 alone cannot initiate apoptosis in myocytes (27). Similarly, p53 may potentiate apoptotic signals but cannot by itself trigger apoptosis (27, 28). However, the accumulation of Bax and the decrease of Bcl-2 with the duration of stretch, in combination with the increase in surface $\mathrm{AT}_{1}$ receptors, provided the molecular basis

Myocyte Stretch

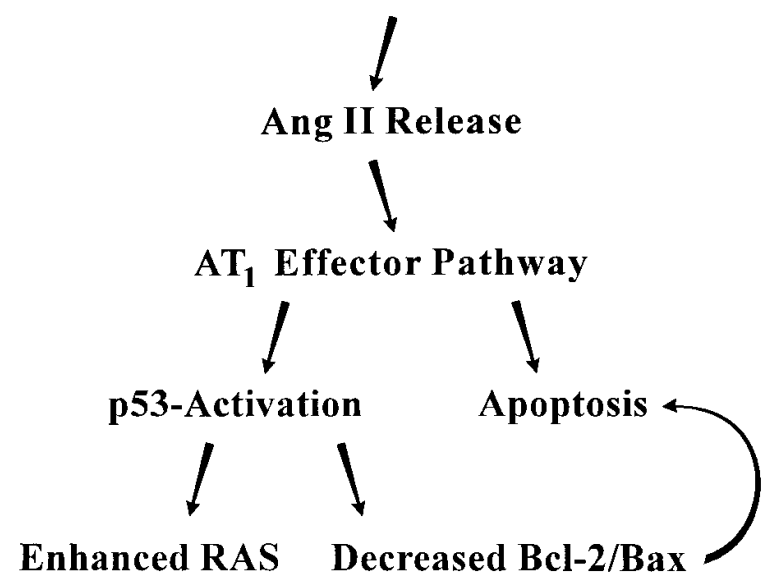

Figure 17. Proposed scheme for stretch-induced apoptosis in myocytes. 
for the enhanced ability of Ang II to trigger the cell death pathway in myocytes. Thus, the hypothesis is advanced that stretch-mediated release of Ang II results in p53 phosphorylation and upregulation of the myocyte RAS which may sustain p53 function and the formation of Ang II. The continuous synthesis of this hormone, in combination with p53-induced decrease in Bcl-2-to-Bax protein ratio, leads to the increase in myocyte apoptosis with time (Fig. 17). Although the extrapolation of in vitro observations to the in vivo state requires extreme caution, the recognition that stretch may be connected to cell death is critical for the heart. Diastolic loads are abnormal in all forms of cardiac failure (56-59) and myocyte apoptosis occurs in the severely impaired human heart $(3,5,48,60)$. Myocyte death facilitates ventricular dilation, counteracts compensatory hypertrophy, and exacerbates the magnitude of loading on the remaining viable cells $(1,2,22)$.

\section{Acknowledgments}

The expert technical assistance of Maria Feliciano is greatly appreciated.

This work was supported by grants HL-38132, HL-39902, HL43023, and AG-15756 from the National Institutes of Health, and by a Grant-in-Aid from the American Heart Association (950321).

\section{References}

1. Katz, A.M. 1995. Cell death in the failing heart: role of an unnatural growth response to overload. Clin. Cardiol. 18(Suppl. IV):IV-36-IV-44.

2. Cohn, J.N. 1996. The management of chronic heart failure. N. Engl. J. Med. 335:490-498.

3. Narula, J., N. Haider, R. Virmani, T.G. DiSalvo, F.D. Kolodgie, R.J. Hajjar, U. Schmidt, M.J. Semigran, G.W. Dec, and B.-A. Kjaw. 1996. Apoptosis in myocytes in end-stage heart failure. N. Engl. J. Med. 335:1182-1189. 1226.

4. Colucci, W.S. 1996. Apoptosis in the heart. N. Engl. J. Med. 335:1224-

5. Olivetti, G., R. Abbi, F. Quaini, J. Kajstura, W. Cheng, J.A. Nitahara, E. Quaini, C. Di Loreto, C.A. Beltrami, S. Krajewski, et al. 1997. Apoptosis in the failing human heart. N. Engl. J. Med. 336:1131-1141.

6. Ross, J., E.H. Sonnenblick, R.R. Taylor, H.M. Spotnitz, and J.W. Covell. 1971. Diastolic geometry and sarcomere lengths in the chronically dilated canine left ventricle. Circ. Res. 28:49-61.

7. Vitali-Mazza, L., P. Anversa, F. Tedeschi, R. Mastandrea, V. Mavilla, and O. Visioli. 1972. Ultrastructural basis of acute left ventricular failure from severe acute aortic stenosis in the rabbit. J. Mol. Cell. Cardiol. 4:661-671.

8. Komuro, I., T. Kaida, Y. Shibazaki, M. Kurabayashi, Y. Katoh, E. Hoh, F. Takaku, and Y. Yazaki. 1990. Stretching cardiac myocytes stimulates protooncogene expression. J. Biol. Chem. 265:3595-3598.

9. Schneider, M.D., R. Roberts, and T.G. Parker. 1991. Modulation of cardiac genes by mechanical stress. The oncogene signaling hypothesis. Mol. Biol. Med. 8:167-183.

10. Sadoshima, J., L. Jahn, T. Takashashi, T.J. Kulik, and S. Izumo. 1992. Molecular characterization of the stretch-induced adaptation of cultured cardiac cells. An in vitro model of load-induced cardiac hypertrophy. J. Biol. Chem. 267:10551-10660.

11. Sadoshima, J., T. Takahashi, L. Jahn, and S. Izumo. 1992. Roles of mechano-sensitive ion channels, cytoskeleton, and contractile activity in stretch-induced immediate-early gene expression and hypertrophy of cardiac myocytes. Proc. Natl. Acad. Sci. USA. 89:9905-9909.

12. Sadoshima, J., and S. Izumo. 1993. Mechanical stretch rapidly activates multiple signal transduction pathways in cardiac myocytes: potential involvement of an autocrine/paracrine mechanism. EMBO (Eur. Mol. Biol. Organ.) J. 12:1681-1692.

13. Pennica, D., K.L. King, K.J. Shaw, E. Luis, J. Rullamas, S.-M. Luoh, W.C. Darbonne, D.S. Knutzon, R. Yen, K.R. Chien, et al. 1995. Expression cloning of cardiotrophin 1, a cytokine that induces cardiac myocyte hypertrophy. Proc. Natl. Acad. Sci. USA. 92:1142-1146.

14. Kent, R.L., and P.J. McDermott. 1996. Passive load and angiotensin II evoke differential responses of gene expression and protein synthesis in cardiac myocytes. Circ. Res. 78:829-838.

15. Baker, K.M., G.W. Booz, and D.E. Dostal. 1992. Cardiac actions of angiotensin II: role of an intracardiac renin-angiotensin system. Annu. Rev. Physiol. 54:227-241.
16. Sadoshima, J., and S. Izumo. 1993. Molecular characterization of angiotensin II-induced hypertrophy of cardiac myocytes and hyperplasia of cardiac fibroblasts. Critical role of the $\mathrm{AT}_{1}$ receptor subtype. Circ. Res. 73:413-423.

17. Sadoshima, J., and S. Izumo. 1993. Signal transduction pathways of angiotensin II-induced c-fos gene expression in cardiac myocytes in vitro. Roles of phospholipid-derived second messengers. Circ. Res. 73:424-438.

18. Sadoshima, J., Y. Xu, H.S. Slayter, and S. Izumo. 1993. Autocrine release of angiotensin II mediates stretch-induced hypertrophy of cardiac myocytes in vitro. Cell. 75:977-984.

19. Cigola, E., J. Kajstura, B. Li, L.G. Meggs, and P. Anversa. 1997. Angiotensin II activates programmed myocyte cell death in vitro. Exp. Cell Res. 231: $363-371$.

20. Kajstura, J., E. Cigola, A. Malhotra, P. Li, W. Cheng, L.G. Meggs, and P. Anversa. 1997. Angiotensin II induces apoptosis of adult ventricular myocytes in vitro. J. Mol. Cell. Cardiol. 29:859-870.

21. Cheng, W., B. Li, J. Kajstura, P. Li, M.S. Wolin, E.H. Sonnenblick, T.H. Hintze, G. Olivetti, and P. Anversa. 1995. Stretch-induced programmed myocyte cell death. J. Clin. Invest. 96:2247-2259.

22. Anversa, P., G. Olivetti, L.G. Meggs, E.H. Sonnenblick, and J.M. Capasso. 1993. Cardiac anatomy and ventricular loading after myocardial infarc tion. Circulation. 87:VII22-VII27.

23. Cheng, W., J. Kajstura, J.A. Nitahara, B. Li, K. Reiss, Y. Liu, W.A. Clark, S. Krajewski, J.C. Reed, G. Olivetti, and P. Anversa. 1996. Programmed cell death contributes to ventricular remodeling after myocardial infarction in rats. Exp. Cell Res. 226:316-327.

24. Olivetti, G., F. Quaini, R. Sala, C. Lagrasta, D. Corradi, E. Bonacina, S.R. Gambert, E. Cigola, and P. Anversa. 1996. Acute myocardial infarction in humans is associated with activation of programmed myocyte cell death in the surviving portion of the heart. J. Mol. Cell. Cardiol. 28:2005-2016.

25. Kajstura, J., W. Cheng, R. Sarangarajan, P. Li, B. Li, J.A. Nitahara, S. Chapnick, K. Reiss, G. Olivetti, and P. Anversa. 1996. Necrotic and apoptotic myocyte cell death in the aging heart of Fischer 344 rats. Am. J. Physiol. 217: H1215-H1228.

26. Bardales, R.H., S. Hailey, S.S. Xie, R.F. Schaefer, and S.-M. Hsu. 1996 In situ apoptosis assay for the detection of early acute myocardial infarction. Am. J. Pathol. 149:821-829.

27. Pierzchalski, P., K. Reiss, W. Cheng, C. Cirielli, J. Kajstura, J.A. Nitahara, M. Rizk, M.C. Capogrossi, and P. Anversa. 1997. p53 induces myocyte apoptosis via the activation of the renin-angiotensin system. Exp. Cell Res. 234: 57-65.

28. Miyashita, T., and J. Reed. 1995. Tumor suppressor p53 is a direct transcriptional activator of the human bax gene. Cell. 80:293-299.

29. Miyashita, T., M. Harigai, M. Hanada, and J.C. Reed. 1994. Identification of a p53-dependent negative response element in the bcl-2 gene. Cancer Res. 54:3131-3135.

30. Cheng, W., K. Reiss, P. Li, M. Chun, J. Kajstura, G. Olivetti, and P. Anversa. 1996. Aging does not affect the activation of the myocyte insulin-like growth factor-1 autocrine system after infarction and ventricular failure in Fischer 344 rats. Circ. Res. 78:536-546.

31. Lee, A.A., T. Delhaas, L.K. Waldman, D.A. MacKenna, F.J. Villarreal, and A.D. McCulloch. 1996. An equibiaxial strain system for cultured cells. Am. J. Physiol. 271:1400-1408.

32. Tournier, J.F., A. Lopez, and J.F. Tocanne. 1989. Effect of cell substratum on lateral mobility of lipids in the plasma membrane of vascular endothelial cells. Exp. Cell Res. 181:105-115.

33. Didenko, V.V., and P.J. Hornsby. 1996. Presence of double-stranded breaks with single-base $3^{\prime}$ overhangs in cells undergoing apoptosis but not necrosis. J. Cell Biol. 135:1369-1376.

34. Reiss, K., W. Cheng, A. Ferber, J. Kajstura, P. Li, B. Li, G. Olivetti, C.J. Homcy, R. Baserga, and P. Anversa. 1996. Overexpression of insulin-like growth factor-1 in the heart is coupled with myocyte proliferation in transgenic mice. Proc. Natl. Acad. Sci. USA. 93:8630-8635.

35. Maunders, M.J. 1993. DNA and RNA ligases (EC 6.6.1.1, EC 6.5.1.2 and EC 6.5.1.3). In Methods in Molecular Biology. Vol. 16. Enzymes of Molecular Biology. M.M. Burrell, editor. Humana Press, Totowa, NJ. 213-230.

36. Gong, J., F. Traganos, and Z. Darzynkiewicz. 1994. A selective procedure for DNA extraction from apoptotic cells applicable for gel electrophoresis and flow cytometry. Anal. Biochem. 218:314-319.

37. Zhang, X., D.E. Dostal, K. Reiss, W. Cheng. J. Kajstura, P. Li, H. Huang, E.H. Sonnenblick, L.G. Meggs, K.M. Baker, and P. Anversa. 1995. Identification and activation of autocrine renin-angiotensin system in adult ventricular myocytes. Am. J. Physiol. 269:H1791-H1802.

38. Hecker, D., G. Page, M. Lohrum, S. Weiland, and K.H. Scheidtmann. 1996. Complex regulation of the DNA-binding activity of p53 by phosphorylation: differential effects of individual phosphorylation sites on the interaction with different binding motifs. Oncogene. 12:953-961.

39. Crissman, H.A., Z. Darzynkiewicz, R.A. Tobey, and J.A. Steinkamp. 1985. Correlated measurements of DNA, RNA, and protein in individual cells by flow cytometry. Science. 228:1321-1324.

40. Wallenstein, S., C.L. Zucker, and J.L. Fleiss. 1980. Some statistical methods useful in circulation research. Circ. Res. 47:1-9.

41. Gold, R., M. Schmied, G. Giegerich, H. Breitschopf, H.P. Hartung, K.V. 
Toyka, and H. Lassmann. 1994. Differentiation between cellular apoptosis and necrosis by the combined use of in situ tailing and nick translation techniques. Lab. Invest. 71:219-225.

42. Mundle, S.D., and A. Raza. 1995. The two in situ techniques do not differentiate between apoptosis and necrosis but rather reveal distinct patterns of DNA fragmentation in apoptosis. Lab. Invest. 72:611-612.

43. Leri, A., Y. Liu, A. Malhotra, Q. Li, P. Stiegler, P.P. Claudio, A. Giordano, J. Kajstura, T.H. Hintze, and P. Anversa. 1997. Pacing-induced heart failure in dogs enhances the expression of p53 and p53-dependent genes in ventricular myocytes. Circulation. 97:194-207.

44. Wada, H., M.R. Zile, C.T. Ivester, G. Cooper IV, and P.J. McDermott. 1996. Comparative effects of contraction and angiotensin II on growth of adult feline cardiocytes in primary culture. Am. J. Physiol. 271:H29-H37.

45. Warren, S.E., H.D. Royal, J.E. Markis, W. Grossman, and R.G. McKay. 1988. Time course of left ventricular dilation after myocardial infarction: influence of infarct-related artery and success of coronary thrombolysis. J. Am. Coll. Cardiol. 11:12-19.

46. Weisman, H.F., D.E. Bush, J.A. Mannisi, M.L. Weisfeldt, and B. Healy. 1988. Cellular mechanisms of myocardial infarct expansion. Circulation. 78: 186-201.

47. Olivetti, G., J.M. Capasso, E.H. Sonnenblick, and P. Anversa. 1990. Side-to-side slippage of myocytes participates in ventricular wall remodeling acutely after myocardial infarction in rats. Circ. Res. 67:23-34.

48. Mallat, Z., A. Tedgui, F. Fontaliran, R. Frank, M. Durigon, and G. Fontaine. 1996. Evidence of apoptosis in arrhythmogenic right ventricular dysplasia. N. Engl. J. Med. 335:1190-1196.

49. Shyu, K.G., J.J. Chen, N.L. Shih, H. Chang, D.L. Wang, W.P. Lien, and C.C. Liew. 1995. Angiotensinogen gene expression is induced by cyclical mechanical stretch in cultured rat cardiomyocytes. Biochem. Biophys. Res. Commun. 211:241-248.

50. Hansen, K.S., and A.W. Braithwaite. 1996. The growth-inhibitory function of p53 is separable from transactivation, apoptosis and suppression of transformation by E1a and Ras. Oncogene. 13:995-1007.
51. Chernova, O.B., M.V. Chernov, M.L. Agarwal, W.R. Taylor, and G.R. Stark. 1995. The role of p53 in regulating genomic stability when DNA and RNA synthesis are inhibited. TIBS (Trends Biochem. Sci.). 20:431-434.

52. Kim, K.K., M.H. Soonpaa, A.I. Daud, G.Y. Koh, J.S. Kim, and L.J. Field. 1994. Tumor suppressor gene expression during normal and pathologic myocardial growth. J. Biol. Chem. 269:22607-22613.

53. Atadja, P., H. Wong, I. Garkavtsev, C. Veillette, and K. Riabowol. 1995. Increased activity of p53 in senescing fibroblasts. Proc. Natl. Acad. Sci. USA. 92:8348-8352.

54. Hupp, T.R., and D.P. Lane. 1994. Regulation of the cryptic sequencespecific DNA-binding function of p53 by protein kinases. Cold Spring Harbor Quant. Biol. 59:195-206.

55. Oltvai, Z.N., and S.J. Korsmeyer. 1994. Checkpoints of dueling dimers foil death wishes. Cell. 79:189-192.

56. McKay, R.G., M.A. Pfeffer, R.C. Pasternak, J.E. Markis, P.C. Come, S. Nakao, J.D. Alderman, J.J. Ferguson, R.D. Safian, and W. Grossman. 1986 Left ventricular remodeling following myocardial infarction: a corollary to infarct expansion. Circulation. 74:693-702.

57. Pfeffer, M.A., G.A. Lamas, D.E. Vaughan, A.F. Parisi, and E. Braunwald. 1988. Effects of captopril on progressive ventricular dilation after anterior myocardial infarction. N. Engl. J. Med. 319:80-86.

58. Pfeffer, M.A., E. Braunwald, L. Moyé, L. Basta, E.J. Brown, Jr., T.E. Cuddy, B.R. Davis, E.M. Geltman, S. Goldman, G.C. Flaker, et al. 1992. Effect of captopril on mortality and morbidity in patients with left ventricular dysfunction after myocardial infarction: results of the survival and ventricular enlargement trial: the SAVE Investigators. N. Engl. J. Med. 327:669-677.

59. Grossman, W., and B.H. Lorell. 1993. Hemodynamic aspects of left ventricular remodeling after myocardial infarction. Circulation. 87:VII28-VII30.

60. Itoh, G., J. Tamura, M. Suzuki, Y. Suzuki, H. Ikeda, M. Koike, M. Nomura, T. Jie, and K. Ito. 1995. DNA fragmentation of human infarcted myocardial cells demonstrated by the nick end labeling method and DNA agarose gel electrophoresis. Am. J. Pathol. 146:1325-1331. 